\title{
A Typology of Intellectual Property Management for Public Health Innovation and Access: Design Considerations for Policymakers ${ }^{\S}$
}

\author{
Antony Taubman
}

Intellectual Property Division, World Trade Organization (WTO), Centre William Rappard, 154, Rue de Lausanne, 121121, Switzerland

\begin{abstract}
This paper seeks to set the practical discipline of public interest intellectual property (IP) management in public health into its broader policy context. The most immediate and direct impact of IP systems on public welfare results not from international standards nor from national legislation - though these norms are fundamentally important - but rather from the accumulated impact of numerous practical choices whether or not to seek IP protection; where and where not; and how any exclusive rights are deployed, by whom, and to what end. IP management is the essentially practical exercise of limited exclusive rights over protected subject matter, the judicious use of those rights to leverage outcomes that advance an institution's or a firm's objectives. Exclusive rights are used to construct and define knowledge-based relationships, to leverage access to technology and other necessary resources, and to enhance market-based incentives. IP management choices range across a broad spectrum, spanning public domain strategies, open or exclusive licensing, and strong exclusivity. The idea of 'exclusive rights', as a specific legal mechanism, can run counter to expectations of greater openness and accessibility, but actual outcomes will depend very much on how these mechanisms are used in practice. For public interest or public sector institutions concerned with health research and development, particularly the development of new medicines, IP management choices can be just as critical as they are for private firms, although a predominant institutional concentration on advancing direct public interest objectives may lead to significantly different approaches in weighing and exercising practical choices for IP management: even so, a private sector approach should not be conflated with exclusivity as an end in itself, nor need public interest IP management eschew all leverage over IP. This paper offers a tentative framework for a richer typology of those choices, to give a sense of practical options available and the factors that might guide their application, but without advocating any particular approach.
\end{abstract}

Keywords: Intellectual property, research policy, patents, innovation.

[Asclepius] freed of their misery, each from his ailment, and led them forth-some to the lull of soft spells, others by potions, still others with bandages steeped in medications culled from all quarters, and some he set right through surgery. But even wisdom feels the lure of gain- gold glittered in his hand, and he was hired to retrieve from death a man already forfeit: the son of Kronos [Zeus] hurled and drove the breath, smoking, from both their chests-savior and saved alike speared by the lightning flash [1].

Asclepius ... introduced medical treatment for those who have a good constitution and lead a healthy life ... and prescribed for them their customary regimen in order not to interfere with their civic duties ... But if a man was incapable of living in the established round and order of life, he did not think it worth while to treat him, since such a fellow is of no use either to himself or to the state. Plato, The Republic, 407 c-e.

*Address correspondence to this author at the Intellectual Property Division, World Trade Organization (WTO), Centre William Rappard, 154, Rue de Lausanne, 121121, Switzerland; Tel: +41 22739 5981; Fax: +412273957 90; E-mail: antony.taubman@wto.org

${ }^{\S}$ This article was commissioned and written prior to the author's current appointment. It should not be construed in any way as advancing an official view; in particular, no views expressed in this article should be attributed to the author in an official capacity; to the WTO, its Secretariat or its Members; nor to WIPO, its Secretariat or Member States. Several passages have benefited from valuable discussions with Roya Ghafele and Anja von der Ropp.

\section{INTRODUCTION}

Pindar recounts how the mythical pioneer of medical practice, Asclepius, was 'struck off' in an extreme fashion by Zeus's thunderbolt - for placing love of gold above a more selfless rationing of his medical skills. He was condemned for 'playing god,' presuming to confront the mysteries of mortality through intemperate, hubristic advances in medical knowledge - a charge with resonances for today's medical researchers as they probe the essence of human genetic identity. And Plato's unflinching utilitarian analysis of Asclepius's clinical case management shows how ancient societies were confronted with tough choices about allocating scarce medical resources. These accounts of the archetypal medical practitioner illuminate a timeless dilemma: should medical resources go to those who can pay for them, to those who are most 'entitled' to them in some principled sense, or to those who will be most beneficial for society? These profound ethical questions - about fairness and social utility in the allocation of that most fundamental of medical resources, knowledge - remain unresolved today.

A 'right to health' (or more strictly a 'right to the highest attainable standard of health') is acknowledged as a fundamental and universal human right ${ }^{1}$, established within

\footnotetext{
${ }^{1}$ Article 25 (1) Everyone has the right to a standard of living adequate for the health and well-being of himself and of his family, including food,
} 
binding international law $^{2}$ and elaborated through guidelines on its implementation [2]. Equitable access to medication is highlighted as a particular aspect of this right [3]; access to medicines is not a stand-alone human right in itself, but is plainly instrumental to assuring the highest attainable standard of health. The General Comment on the International Covenant accordingly recognizes as a "core obligation' on States parties to "provide essential drugs, as from time to time defined under the WHO Action Programme on Essential Drugs."

But disease is not static and is unequally distributed, and medicines are not simple commodities like clean water, in the sense that water has essentially the same utility for all humanity. In medicine, innovative activity that benefits some populations may be little or no use to others which may be in greater need of life-saving medicines: thus, equitable and effective access to medicines arguably entails a fair distribution of the innovation effort, too, so that research and development must not be inequitably focused on the health needs of the wealthy, and must track and respond to the changing clinical environment and infrastructure needs of the poor; equally, making drugs available in the absence of broader clinical support can be ineffective, or in some cases actively counter-productive. ${ }^{3} \mathrm{~A}$ comprehensive and realistic view of access to medication must, therefore, take account of the innovation process itself and broader infrastructure needs. It cannot focus solely on distributive equity in the allocation of finished pharmaceutical products. Hence the international debate over a right to health and access to medicines has broadened to a full-fledged policy process about innovation to address neglected health needs. ${ }^{4}$

clothing, housing and medical care and necessary social services ... Universal Declaration of Human Rights, adopted by the United Nations General Assembly (A/RES/217, December 10, 1948); also relevant are Articles 27 and 17.

${ }^{2}$ International Covenant on Economic, Social and Cultural Rights, adopted and opened for signature, ratification and accession by General Assembly resolution 2200A (XXI) of 16 December 1966 (entry into force 3 January 1976) ('the International Covenant'). Article 12 provides:

The States Parties to the present Covenant recognize the right of everyone to the enjoyment of the highest attainable standard of physical and mental health.

The steps to be taken by the States Parties to the present Covenant to achieve the full realization of this right shall include those necessary for:

(a) The provision for the reduction of the stillbirth-rate and of infant mortality and for the healthy development of the child;

(b) The improvement of all aspects of environmental and industrial hygiene; (c) The prevention, treatment and control of epidemic, endemic, occupational and other diseases;

(d) The creation of conditions which would assure to all medical service and medical attention in the event of sickness.

${ }^{3}$ Clinical mismanagement of tuberculosis, for instance, can promote the development of drug-resistant strains, as epitomized by reports that extensively drug-resistant tuberculosis (XDR-TB) resulted from mismanagement of multidrug-resistant tuberculosis (MDR-TB), see World Health Organization, Drug- and multidrug-resistant tuberculosis (MDR-TB), at http://www.who.int/tb/challenges/mdr/en/index.html, and Global tuberculosis control - epidemiology, strategy, financing, WHO Report 2009, $\mathrm{WHO} / \mathrm{HTM} / \mathrm{TB} / 2009.411,2009$.

${ }^{4}$ See, for instance, the work of the Commission on Intellectual Property Rights, Innovation and Public Health (CIPIH), established by the World Health Assembly in 2003 “...to collect data and proposals from the different actors involved and produce an analysis of intellectual property rights, innovation, and public health, including the question of appropriate funding

\section{SCARCITY OF RESOURCES \& UNIVERSALITY OF ACCESS}

The challenge of implementing a universal right to health is that, in practice, it entails the allocation of medical resources that are inherently scarce and necessarily rivalrous (by contrast, enjoying freedom of speech does not deny others that right), and modern medicine is increasingly resource-intensive (by contrast, the technological infrastructure required effectively to exercise freedom of expression is falling in relative cost). Rationing medical resources to fulfil a universal right to health is problematic whether the resources in question essentially concern direct patient care (e.g. skilled medical workers), the environment that sustains health (medical infrastructure, medications, and broader needs such as the availability of safe drinking water), or those applied to researching and developing new medical treatments (research capacity, financial and human capital, research and development infrastructure, and developmental, clinical and regulatory capacity). A further, fundamental - from some perspectives, controlling - factor is that for the most part society has, by default, largely chosen to leave the intermediate and final stages of development of new pharmaceutical products to the private sector; while other models for drug discovery and development are actively explored, there are few examples of new medications that have been developed into finished, effective and clinically-proven products solely through public sector institutions, without the involvement of at least some private sector resources along the development pipeline, so that in practical drug development public interest and public resources are intrinsically mixed with private interests and private resources. Some commentators respond to this status quo by calling for more active and better resourced public sector programs of new product development, for stepped up public funding and control of the full research and development pipeline, and for alternative innovation structures that decouple the economics of drug development from the market for finished products.

No view is advanced in this paper on the legitimacy or the relative efficiency and equity of any existing or potential future models, a broader policy debate not touched upon here. But, for the immediate present, one must address the current state of affairs - a complex interplay of public and private interests - in considering how practically to promote universal, equitable access to medications. To the extent that it is the private sector that brings new medications to the dispensary, firms can be expected to allocate their resources so as to promote their commercial interests, given that company management is under a fiduciary duty to do so. And if public sector institutions need to cooperate with firms can engage private sector resources to yield public health outcomes in practice, then these institutions will need to

and incentive mechanisms for the creation of new medicines and other products against diseases that disproportionately affect developing countries..." and the ensuing Intergovernmental Working Group (IGWG) established under Resolution WHA59.24 to draw up a global strategy and plan of action aimed at, inter alia, securing an enhanced and sustainable basis for needs-driven, essential health research and development relevant to diseases that disproportionately affect developing countries. 
acknowledge and accommodate legitimate commercial motives - the same "lure of gain" [4]. But need these distinct interests be set permanently or intrinsically at odds with one another, in an essentially zero-sum analysis? Or is it analytically and practically more productive to work from the assumption that these two sets of interests (to the extent that they can be coherently clumped together at all) can not only be reconciled, but indeed may be mutually dependent and potentially synergetic in a mixed market economy? It is that goal - the conscious construction of non-zero-sum forms of working with biomedical knowledge that can advance legitimate private interests while focusing on attaining public health interests - that some strategies for public-interest IP management in the field of health work towards.

Given this backdrop of scarcity, and rivalry over resources, it is unsurprising that some proponents of a right to health view the $\mathrm{IP}^{\mathbf{5}}$ system as being inherently at odds with attaining universal access to appropriate health care, or at least discern deep conceptual tension between the right to health and the rights attached to IP, requiring the active intervention of governments [5], a conscious process of reconciliation between different normative goals, or the assertion of the primacy of fundamental human rights over the more contingent, utilitarian rights granted under an IP law. The central legal logic of an IP law system is that it sets out rights to exclude third parties - rights to say 'no', or to set conditions, for others' use of certain protected material - in other words, it creates exclusions from the public domain. ${ }^{6}$

${ }^{5}$ Two distinctions may be helpful in guiding discussion: first, between IP and patents as such; second, between IP and an IP 'right' or between a patent and a patent 'right'. On the first, 'IP' can at times serve in discussion as a metonym for patents (or a synecdoche, using the genus to denote the species) in the public health and human rights debate, at times misleadingly so. The most conspicuous instance of this conflation is TRIPS art. [7], which appears - despite its authoritative articulation of the objectives of IP protection - to be focused, through its references to 'the promotion of technological innovation,' 'the transfer and dissemination of technology' and 'producers and users of technological knowledge' to more on patents (and to a lesser extent undisclosed information and test data, designs and the technological dimension of copyright), than on the full sweep of 'IP' (embracing, for instance, geographical indications, trademarks and the aesthetic dimension of artistic works). On the second, the conventional conflation between, say, a patent, and a 'patent right' may lead to a loss of information, just as my ownership of a plot of land cannot be conflated with the ensuing rights to exclude others from that land: grant of a patent carries with it certain rights to exclude third parties from certain actions, and critics of the patent system may object to the reification of a patent as a form of property in itself, but there is nonetheless a key operational distinction crucial to this article - between the fact that I am registered as owning a patent, and the limited rights to object to third parties' activities that result from my ownership of the patent: once again, TRIPS is an illustrative case study, focused as it is more on the 'rights' associated with IP than it is with IP as such (TRIPS is in general silent on questions of ownership and assignment of IP, a point reinforced in the Appellate Body Report, United States - Section 211 Omnibus Appropriations Act of 1998, WT/DS176/AB/R, adopted 1 February 2002, DSR 2002:II, 589). The panel decision in Canada - Patent Protection of Pharmaceutical Products, WT/DS114/R, adopted 7 April 2000, DSR 2000:V, 2289 clarified that there was no 'hierarchy of patent rights' within TRIPS: ' [i]f the right to exclude sales were all that really mattered, there would be no reason to add other rights to exclude "making" and "using". The fact that such rights were included in [TRIPS], as they are in most national patent laws, is strong evidence that they are considered a meaningful and independent part of the patent owner's rights' (at p. 156).

${ }^{6} \mathrm{~A}$ broader reading of IP law includes mechanisms that do not create a right to exclude as such, but enable a claim for equitable remuneration, a right to
Typically, given the concentration of patent ownership in the commercial sector, the right to exclude others from the material protected by patents is normally exercised so as to promote a firm's or an individual's own commercial interests: "the normal practice of exploitation by patent owners, as with owners of any other intellectual property right, is to exclude all forms of competition that could detract significantly from the economic returns anticipated from a patent's grant of market exclusivity" [6]. The law of human rights does recognize a 'right to protection of the moral and material interests resulting from any scientific, literary or artistic production of which one is the author' [8]; this human right is potentially promoted by (but should not be conflated with) the rights flowing from tenure of IP. Authoritative commentary stresses that this human right is itself subject to 'limitations in the public interest' [8], setting this particular right into a utilitarian context.

Thus, at first blush, it is assumed that the IP system is predisposed towards the kind of mercenary approach that provoked the ire of Zeus, and the capital punishment of Asclepius: rationing scarce healing capacity according to ability to pay. In a public health environment already hampered by scarcity, what is the policy logic of promoting a legal mechanism that can only work by imposing exclusion, exclusion from the use of that very medical knowledge that is desperately needed to promote public health, thus fulfilling the hope for equitable public health outcomes for all? This normative tension is articulated at the level of formal international policy discourse: "since the implementation of the TRIPS Agreement does not adequately reflect the fundamental nature and individuality of all human rights, including the right of everyone to enjoy the benefits of scientific progress and its applications, the right to health, the right to food and the right to selfdetermination, there are apparent conflicts between the intellectual property rights regime embodied in the TRIPS Agreement, on the one hand, and international human rights law, on the other [9]."

\section{METHODOLOGY OF THIS ARTICLE}

This article explores these policy dilemmas and 'apparent conflicts', with a view to elaborating the potential functional role of IP mechanisms, ${ }^{7}$ particularly the practical exercise of patents, in promoting public policy outcomes in the field of human health, in line with the "right to health" of human right law. This article does not focus on the substantive elements of human rights law, nor on international and national patent laws and standards - patentability, exceptions and limitations, compulsory licensing, etc. - that have recently preoccupied international policymakers and much

be acknowledged, and a right to object to certain objectionable forms of use (including distorting or derogatory uses, or unfair competition); the general point here is that overall the 'right' granted under an IP system is normally a right to exclude in its essential legal character.

${ }^{7}$ The paper concentrates on the patent system as a crude proxy for IP mechanisms more generally, to some extent making the conflation noted above (note 5); a full review would need at the very least to address cognate areas of law, such as test data protection and knowhow/trade secrets, as well as other forms of IP such as the role of trademarks in enabling humanitarian price discrimination. 
policy debate. The approach taken is firstly to review the general context of IP policymaking, and then to highlight the impact of specific choices undertaken within the framework of the patent system. This is not to suggest for a moment that this focus is comprehensive or sufficient in itself; this approach merely supplements and may inform a more comprehensive account of the patent system and its implications for the right to health, and certainly does not substitute for such a wide-ranging analysis. This supplementary approach may nonetheless be useful since the ultimate actual impact of the patent system is felt not from the mere presence or absence of a formal system of assessing, granting, and enforcing patents, but from the judicious, skillful application and regulation of these legal mechanisms in practice. Overall positive welfare gains for public health that may flow from the patent system would emerge from an accumulation of individual practical choices to apply for and to deploy specific IP rights, not solely from the relatively abstract process of shaping the legislative framework within which rights are deployed. Equally, tangible harms that are actually felt in practice would result also from particular choices about how individual IP rights are exercised in practice, and not directly from the passage of stronger or weaker patent legislation, nor immediately from the decision to grant or refuse a patent on an application (again, this is not to suggest that these broader factors are not fundamentally important - it is just to recall the significance of accumulated choices concerning the practical exercise of any patent rights once granted). Accordingly, this article considers the practical role of patents when actively, directly implemented with the explicit goal of promoting positive public health outcomes. In short, it considers how the exclusive rights established under IP law are, can be, or should be, deployed to achieve the inclusive goal of universal access to necessary health care.

This article therefore develops the concept of publicinterest or public-sector IP management, concentrating on the management of IP directly to leverage public health outcomes. It forms part of a broader body of analytical work that seeks to address:

- the policy background to public-sector IP management, and how to reconcile the apparent contradiction between the exercise of exclusive rights and the promotion of public health outcomes;

- the elements of a distinct discipline of public interest IP management, considering them from both the normative and the practical aspects, distinguished from the regular, commercially-oriented management of IP;

- $\quad$ policy lessons that may be derived from the practice of public-interest IP management, that may apply to the broader management and regulation of knowledge in the public interest.

Framing these questions in this way is not intended to suggest that the management of patents by private concerns to promote the legitimate commercial interests of firms is inherently at odds with the public interest. According to conventional analyses, the patent system serves a valuable role in harnessing and focusing private interest towards broader, socially beneficial outcomes, that may not be achieved without, to use the stock phrase coined by Lincoln, "the fuel of interest" [10]. Indeed, the very basis of the patent system is the consistent determination over many years by policymakers that the public interest is actively served by yoking private interest and directing it towards welfare-enhancing innovation: "the discovery and production of new and useful things [10]."

Proponents of the patent system typically stress that it provides private actors with a rational incentive to invest in socially valuable research and development. But when it comes to delivering the benefit of innovation, private incentive is often viewed as conflicting with the public's need for optimal access to new technologies. The logic of IP rights is to exclude: creating a private right to deny or limit to third parties the use of what is protected. This creates a seeming paradox: a policy tool that is meant to promote public welfare in new technologies operates by excluding access to those technologies.

\section{POLICY BACKGROUND}

Squaring this circle has been a continuing legal and policy challenge from the early days of the patent system: how to stimulate beneficial innovation by private players, while ensuring the public enjoys tangible benefits, or 'innovation and access,, 8 as it is currently expressed. ${ }^{9}$ Public and private domains of knowledge have evolved over time in a contested, dynamic search for the right balance, not as a static zero-sum tradeoff but through positive sum synergies. Anglo-American patent law draws its roots from a Jacobean text, the 1623 Statute of Monopolies ${ }^{10}$, which aimed to eliminate harmful monopolies based 'upon misinformations and untrue pretences of public good.' From this procompetition standard (supporting also the right to ply one's trade without undue restraint), legislators consciously carved out an exception for legitimate patents of inventions. This provision, in effect an early patent law, reflected a practical judgement that such exclusive rights could serve public and private interests in conjunction, and that immediate open public access for all inventions would have the effect of impairing the public interest. That paradox again: limited exclusion as a public good.

Following this approach, the task of an utilitarian and objective IP policymaker boils down to determining what privately-held exclusions from the public domain of otherwise non-excludable knowledge resources are required to harness sufficient private interest to provide for the production of useful public goods that would not otherwise

\footnotetext{
${ }^{8}$ See, e.g. Médecins sans frontières, Twin problems, one solution: tackling innovation and access together, at www.accessmed-msf.org/main/accesspatents, and KEI, Medical Innovation and Access, at http://www.keionline. org

${ }^{9}$ See also Innovation and Access to Knowledge Programme, South Centre, at http://www.southcentre.org

${ }^{10}$ Statute of Monopolies, 1623, 21 Jac. 1, c. 3,
} 
come into existence. ${ }^{11}$ But how does the objective policymaker, ideally in the original position behind a Rawlsian veil of ignorance [12], determine what exclusions would be just; or legitimate; or effective; how does the policymaker establish a hierarchy of public goods, say between the goods of a pragmatic effectiveness and formal equity? From this perspective, a possible utilitarian line of analysis would, in effect, adapt the classical liberal economic analysis (the 'invisible hand') ${ }^{12}$ and apply it to the intangible goods generated by the IP system: public goods result from the pursuit of private interest, as the spontaneous ordering of the market and communication through market exchange promotes beneficial investment and innovation. ${ }^{13}$

Classically applied to goods and services, ${ }^{14}$ this analysis may extend to the harnessing of private interest to produce intangible knowledge products of benefit to society. By such an analysis, at least, certain exclusions from the public domain would capture and direct private interest towards the production of public goods that would otherwise not exist: paradoxically, a conscious system of exclusion from the public domain may provide for spontaneous ordering that works for society's gain: ${ }^{15}$ provisionally privatizing new knowledge through statutory exclusions may help convert abstract knowledge into tangible public goods. Yet, as soon as this analysis is articulated, it can be suspected as effectively defending exclusive rights as ends in themselves; other participants in the debate find it problematic to invest simple faith in the beneficial operation of private rights as spontaneously advancing the collective public interest, when

\footnotetext{
${ }^{11}$ This is not, of course, by any means the mechanism for harnessing private interest to provide for public goods. There is, for example, a considerable economic literature on the private provision of public goods, considering such phenomena as corporate philanthropy, political campaign donations. See Eduardo Ley, 'On the Private Provision of Public Goods: A Diagrammatic Exposition,' Investigaciones Economicas, 20:1 (January 1996), 105123, at IMF, Washington DC, http://econwpa.wustl.edu/eprints/pe/papers/ 9503/9503001.abs. See the economic model for non-cooperative provision of public goods in Theodore Bergstrom, Laurence Blume, and Hal Varian, Private Provision of Public Goods, Journal of Public Economics, 29:25-49 1986. at http://econwpa.wustl.edu/eprints/pe/papers/9503/9503001.abs

${ }^{12}$ For a brief historical review of these aspects of liberalism, see Steven Horwitz, From Smith to Menger to Hayek: Liberalism in the Spontaneous Order Tradition, The Indep. Rev., 6 (1), Summer 2001), at 81.

${ }^{13}$ Compare Adam Smith's classic formulation: "by directing that industry in such a manner as its produce may be of the greatest value, he intends only his own gain, and he is in this, as in many other cases, led by an invisible hand to promote an end which was no part of his intention. Nor is it always the worse for the society that it was no part of it. By pursuing his own interest, he frequently promotes that of the society more effectually than when he really intends to promote it."

${ }^{14}$ With the assumption that intangible knowledge products are not economically significant: note Smith's reference to the intangible or ephemeral product of "players, opera-singers, opera-dancers, etc." as producing "nothing which could afterwards purchase or procure an equal quantity of labour. Like the declamation of the actor, the harangue of the orator, or the tune of the musician, the work of all of them perishes in the very instant of its production." Adam Smith, An Inquiry into The Nature and Causes of the Wealth of Nations 119 (Henry Frowde ed., Oxford Univ. Press 1909) (1776).

${ }^{15}$ The imposition of an exclusion means that they cease to be true public goods, as these are by definition not excludable, but the disclosure requirements of technology-related IP protection are intended to ensure that protected subject matter passes into the public domain firstly as a public knowledge good (patent information is not, in principle, excludable from the time of its publication), and, through limited term.
}

the policy tool applied is one of exclusion: intuitively, at least, it can go against the grain for a policy aimed at providing for public goods (which are by definition not excludable) to operate through the exercise of exclusive rights. In principle, the tension may be resolved through some key distinctions. First, if the desired public good is available knowledge as such - material in the public domain of knowable information - then the function of the patent system is to deliver technological teaching into that form of public domain; new knowledge must be published and publicly available for a valid patent to be granted. Second, if the ultimate objective is the production of tangible public goods, then the protected innovation is in itself only an intermediate towards that end - knowledge about therapeutic properties of a new compound is not the same thing as the provision of a concrete, safe, effective and stable product in the pharmacopoeia and stocked by dispensaries worldwide. Equally, the 'right to health' - the entitlement to receive a certain standard of medical treatment - is not the same thing as the right to make commercial use of a particular form of pharmacological know-how. In practice, as noted, society has often elected to use market-based mechanisms for funding the final practical development of new medications. Leaving aside the broader question of whether this was the optimal choice, it offers empirical evidence that exclusive rights, properly defined and regulated, can serve as at least one means of financing and furnishing socially valuable public goods.

Even so, there is a history of concern that policy tools that rely on exclusive rights may be subject to excessive influence by sectoral interests and regulatory capture. Principled resistance has long been asserted against economic privileges and the kind of special pleading that their beneficiaries can use to justify them. Commenting on the mercantilist tendency to grant monopolies in the early industrial age, when patent law was being gradually distilled out of the general law of monopolies as a legitimate exception, Marshall observes that "restrictive regulations, which have an indirect constructive result in promoting national power and dignity, are rightly judged with exceptional favour. But this fine feeling is not without its perils; for it is apt to be turned to account by persons who stand to gain by the restrictions. Such persons are most dangerous when they are honestly convinced, as they often are, that they are striving for the public good as well as their own [13]." He refers to "sectional jealousies" provoked by monopolies that enabled the suppression of "inconvenient rivals." 16 This tendency to special pleading underscores the need for objective principles to determine the utilitarian benefit of such restrictions, so that they become a genuine mechanism for social benefit and not a bare favour or sectional privilege. Substantive patent law provides a distillation of these public policy principles, and the continuing application of patentability criteria provides one public-interest safeguard against the simple accommodation of private interests.

\footnotetext{
${ }^{16}$ Ibid. amplifying, in a footnote, he comments "in some cases plausible reasons were suggested: and indeed the Tudors were masters of the fine art of writing preambles."
} 
Perhaps this logic might hold together when society relies on private innovation to serve the public interest, if one moves away from a static, zero-sum view of innovation, and accepts that the public expects private investment to develop new technologies as finished products. But does this logic apply when the public pays for research? Shouldn't fruits of that research enter the public domain, and not be shrouded in exclusivity? Traditionally, management of public research has taken this approach, effectively conflating the public domain and the public good. Yet the growing realization that this choice can - in practice, and in some specific circumstances - work against the public interest yields a fundamental insight into the nature of innovation in a market economy. Of course much research resides properly in the public domain: the human genome is an iconic instance. ${ }^{17}$ Private interests also choose to defend their interests by pre-emptively placing some research in the public domain through defensive publication, in such cases regarding their continuing freedom to operate as being commercially more valuable than the right to exclude their competitors from using this information.

In practice, though, to apply public research insights and to transform them into practically available new technologies requires judicious use of a wider range of tools than reliance on public domain status. Eschewing exclusive rights altogether may mean that public research is available on the library shelf, but that there is no viable pathway for those who need to invest risk and resources into its practical employment and transformation into usable products. When concerns arise over the impact and effectiveness of public funding, it can mean that private foreign interests may benefit more from public-funded innovation, effectively free-riding on research, developing and applying it, and creating new products which are sold back to the originating country. Knowledge management solely through channeling research into the public domain can mean that others decide how the research outcomes are taken up, if at all, and who is to benefit, and that research sponsors lose any say over now these outcomes.

\section{KNOWLEDGE MANAGEMENT AND PUBLIC GOODS}

At one level, knowledge is the definitive public good like safe water and clean air. Yet given the practical dilemmas over effective management of public research, an appropriate system of knowledge governance and public innovation policy - systemic IP management to advance public welfare - is in itself a higher order public good; medical knowledge in itself is a public good, but a well ordered mechanism for managing that knowledge to advance

\footnotetext{
${ }^{17}$ Then British Prime Minister Tony Blair and then-U.S. President Bill Clinton on March 14, 2000 stated that " [t]o realize the full promise of this research, raw fundamental data on the human genome, including the human DNA sequence and its variations, should be made freely available to scientists everywhere. Unencumbered access to this information will promote discoveries that will reduce the burden of disease, improve health around the world, and enhance the quality of life for all humankind. Intellectual property protection for gene-based inventions will also play an important role in stimulating the development of important new health care products." (accessed at: http://clinton4.nara. gov/WH/EOP/OSTP/html/00314.html).
}

actual public well-being may be considered a public good at a different plane of analysis. Public resources are invested in generating the public good of knowledge, but are equally invested in creating a knowledge management infrastructure (legal and administrative) that enables society to extract practical benefit from that knowledge. Hence shrewd, informed and objective use of exclusive IP rights is one element of the mix of policy measures to transform research insights into tangible public benefit. This entails recognizing where the public domain and the public interest diverge, and managing exclusive rights to focus resources on beneficial innovation and the optimal practical application of that innovation.

Indeed, actual patterns of innovation for public health the life cycles of real products - confute a priori assumptions of a fundamental choice between private or public good structures, or between favouring the impetus of exclusive private rights or directly promoting the public interest. The plurality of approaches to ownership and control of patented technology increasingly illustrates the practical distinction between privately-held rights to exclude and private interests as such: a significant proportion of patenting activity in the public health domain is by government agencies, public institutions or other public-interest bodies. Accordingly, the grant and exercise of 'private rights, ${ }^{18}$ need not be solely or even marginally directed towards private interest: it is increasingly inaccurate to conflate the private or exclusive nature of IP rights with the narrow pursuit of private interest. IP management that is solely and explicitly directed towards promoting public interest outcomes can include defensive publication and the pre-emptive creation of a public domain (including by waiving IP rights ${ }^{19}$ ), but it also includes the judicious deployment of legal exclusions.

For instance, the IP-based right to exclude certain uses of protected materials can be used to encourage direct allocation of private resources towards public interest outcomes, in the absence of market incentives: this is the essence of IP management in public-private partnerships. Exclusive rights can be licensed to preclude commercial use of protected materials, to promote non-commercial creative exchange and adaptation. ${ }^{20}$ The judicious application of the right to exclude can be used to safeguard the open quality of a shared innovative domain for agricultural biotechnology (exercising exclusive IP rights to preclude third parties from

\footnotetext{
${ }^{18}$ Compare the preamble of the WTO TRIPS Agreement ('Recognizing that intellectual property rights are private rights') with the growing stock of publicly-held patents - private rights held and exercised nonetheless by public institutions, even government instrumentalities such as ministries of health.

${ }^{19}$ See for example the public domain dedication of the Eldritch Press: "Eric Eldred hereby releases any creative addition to the literary materials at the Eldritch Press - including but not limited to any copyrightable compilation of materials or HTML formatting - to the public domain with a Creative Commons Public Domain Dedication." (at http://creativecommons.org/ licenses/publicdomain/eldred/)

${ }^{20}$ See for example the 'Attribution-NonCommercial-ShareAlike 1.0 ' draft license at (UK) : "You may not exercise any of the rights granted to You in Section 3 above in any manner that is primarily intended for or directed towards commercial advantage or monetary compensation." (at http://creativecommons.org/worldwide/uk/, last visited May 14, 2005)
} 


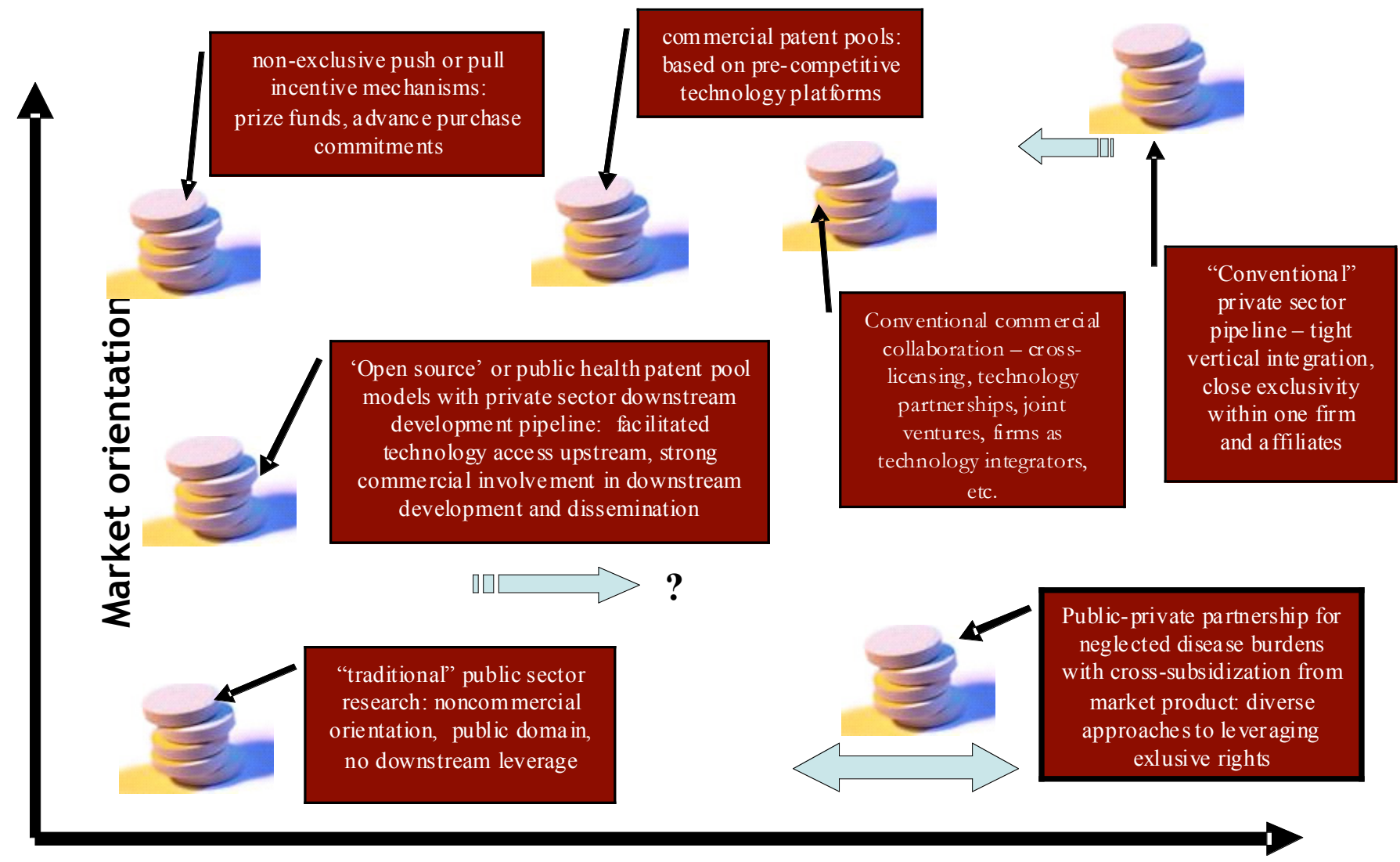

\section{Exclusivity/leverage over technology}

Fig. (1). Mapping the options for drug innovation structures according to the degree of market engagement to provide incentive to bring the product through the development pipeline and the degree to which exclusivity or leverage is exercised over the core technologies. This Figure is potentially useful only as an illustration of the range of possibilities and practical design issues in shaping a strategy and is not a precise analytical tool; actual choices vary more considerably - for example, some public private partnerships entail complete nonexclusivity.

excluding open access to derivative technologies). ${ }^{21}$ Standards bodies use IP licensing structures to ensure open access to standards while encouraging technology developers to pool their technologies for mutual benefit, such as by defining fair, reasonable and non-discriminatory (FRAND) terms and conditions for licenses. ${ }^{22}$ The claim for protection of traditional knowledge is expressed by some proponents, at least, as a collective right or custodial responsibility to prevent illegitimate use of this knowledge, entailing the

\footnotetext{
${ }^{21}$ See for example Biological Open Source License for Genetic Resources Indexing Technologies at http://www.bios.net/daisy/GRITLicense/750/1170. $\mathrm{html}$

${ }^{22}$ Concerning the resolution of conflict between the exclusivity of IP rights and open access to standards in the United Kingdom, "most standards bodies include procedures that take IPRs into account where a standard is in the process of being drawn up. Each participant is expected to declare at an early stage the IPRs it holds which are (or might be) essential to the draft standard if it were to be adopted. The owner is requested to give an undertaking in writing that it is prepared to grant irrevocable licences on royalty-free or fair, reasonable and non-discriminatory (FRAND) terms and conditions under such IPRs, with a waiver of copyright in documentary material. The standards body also makes sure that the patent in question is endorsed as a 'Licence of Right' at the Patent Office. This ensures that licences under the patent are available to all applicants as of right and that any disagreement of licensing terms is subject to settlement by the Patent Office," Matthew Clarke, Standards and Intellectual Property Rights (2004),
} at 64 . exercise of rights to exclude third parties in the name of $a$ public if not the public - i.e. the traditional community which maintains the knowledge according to customary law and practice [14]. Programs of public sector knowledge management that entail obtaining and asserting IP rights can be construed as a form of privatisation of public knowledge, or idealized as a means to maintain collective public-interest control over how public knowledge is developed and applied.

\section{HEALTH INNOVATION STRUCTURES IN PRACTICE}

Innovation practices and structures developed to deliver public health outcomes typically do not correspond absolutely to one or other of the conventional antinomies of public $v s$ private, or exclusive rights $v s$ open innovation; just as the values driving innovation are more protean than a neat cleavage between open altruism and closed self-interest. Actual development and effective delivery to the public of life sciences products employ a blend of public, private but part publicly-funded, and strictly private inputs, with emphasis varying as to the preferred end of a diverse spectrum of inputs and structures. There is rarely a one-toone correspondence between one patent, or one licensing model, or one genetic input, on the one hand, and an actual 
complex product such as a new drug or vaccine, which in its available and functional form will be a convergence of inputs: genetic material, knowhow, foreground inventions, platform technologies and test data. The necessary cluster of diverse technological inputs will be governed, licensed and made available in diverse ways ultimately to yield a practical product that draws together elements of each of these inputs. This makes it almost inevitable that a hybrid mix of forms of knowledge management will be employed along the full, extended pipeline of actual product development. As the above figure (Fig. 1) illustrates, innovation structures make use of a range of options between fully open access and exclusivity, on one axis, and between different levels of engagement with the market on the other axis. The knowledge management task for the product innovator whether public or private, or both - entails determining what position on this landscape is likely to achieve the practical outcomes desired, recognizing that at least some leverage over technology and some engagement with the market will likely be required. For the public-sector or public-interest knowledge manager, there will be a special responsibility to ensure that engagement with market dynamics and the exercise of exclusive leverage do not become ends in themselves, but remain strictly instrumental towards the overarching goals of the innovation project.

A bare dichotomy between public and private forms of management is likely to be insufficient to describe actual patterns of behavior, or to guide future practical choices. A more comprehensive working typology of these innovation structures and mechanisms may, therefore, be constructed on the basis of different choices along the two axes of public/private resources engaged, and the degree of exclusivity or openness employed. A further factor that may inform such a typology is the manner in which the 'fuel of interest' is ignited - in other words, the incentive mechanism that is used to engage and direct any necessary private resources (including financial, capital and intellectual resources, but also the capacity of the private sector to manage risk and liability). The potential range of incentive mechanisms can be characterized, again, by the extent of reliance on the market as against direct grants or prizes, and the extent to which exclusivity is employed as an incentive. Thus the range of incentive options includes the conventional incentive of potential participation in the market based on defined exclusive rights over a technology or over a regulatory approval dossier, and transferred incentives in which interests based on a certain technology or a defined market are used to promote a guaranteed level of support for a neglected technology or patient group - such as using exclusivity in a wealthy market to subsidize access and distribution in a developing country, or a public sector/philanthropic market; or using a larger market to cross subsidize readiness for another area of need (such as paediatric formulations); or using exclusive rights over adaptive or secondary use technologies (when these are genuine inventions) to enable the development of an existing treatment for other defined needs. The options also include prize funds and direct grants for research, which may aim at creating strong incentives for innovation and investment in risky research, while not requiring the prospect of future exclusive rights to serve as the principal incentive - as it is presented in current debate, delinking the market for innovation from the market for pharmaceuticals.

IP management is in principle technology-neutral; the same basic legal tools apply where the technology concerns public health or new construction techniques. However there are several fundamental considerations that set apart the life sciences, and medical technology especially, which may influence the choice of IP management strategy and techniques.

- These technologies are closely associated with human rights and fundamental human needs concerning health.

- Medical technology attracts a higher than usual share of public or philanthropic funding, and other public resources (such as research facilities).

- There are high expectations that the benefits from new technologies will flow directly to the public.

- Ethical considerations may apply, bolstered by the human rights dimension, such as the ethical implications of too restrictive an approach to granting access to key technologies;

- $\quad$ pharmaceuticals are developed and exercised within a complex regulatory environment, to ensure safety and efficacy; this can mean that the dynamics, required resources and incentive structures for the development and dissemination of new technologies can differ considerably from other technical fields.

Even so, public sector/public interest philanthropic research and development aim at a range of different objectives, shaped by government policy, funding initiatives, institutional goals and objectives, and the specific aims of individual researchers and research programs. What is considered to be in the "public interest" will therefore differ considerably, and will in turn flavor IP management choices, depending on whether they aim, for example, to:

- create new medical treatments and disseminate them as widely as possible;

- $\quad$ capture the benefits of indigenous research and development to promote local economic growth and sustainable development, including using traditional medical knowledge as the basis of innovative industries;

- $\quad$ secure additional resources through licensing and other commercial arrangements to support further research to promote the advancement of scientific knowledge;

- create enabling tools and an enabling environment for more widely dispersed and broadly based medical innovation, to promote greater participation in the 


\author{
innovation process by its intended \\ beneficiaries; or \\ - create a viable research-based industry \\ sector through the formation of new \\ commercial entities.
}

Each of these objectives represents a slightly different reading of what is the 'public interest.' While these objectives are not necessarily mutually exclusive, and indeed may overlap in practice, a strong emphasis on one or the other may well lead to different practical choices in how public sector/public interest IP management is conducted. Accordingly, no one model of IP management is likely to serve the public interest. The choice of IP management model should, therefore, follow policy guidance on what public interest objectives are to be pursued; this is more likely to lead to concrete public benefits than an approach that emphasizes the choice of management structure over the broader definition of objectives.

Clearly, the practical impact and legal implications of different weightings of these various factors will differ dramatically, and no one model is likely to serve as an optimal choice for all technology development and diffusion requirements relating to neglected health needs. For example, the range of mechanisms reflecting different approaches to the deployment of exclusive patent rights include the following:

- Patent pools: Definitions of patent pools vary greatly, but the essential idea is that participating patent holders agree to license their technologies to one another - some are termed a 'joint licensing scheme'. Usually the technology is in a well-defined field, or specific patents may be identified. A closed patent pool would restrict access to technology, raising potential concerns about anticompetitive impact if it excludes legitimate competition by those not taking part in the pool. An open patent pool would enable access by any party to the technologies covered, provided they met the standard conditions and undertakings under the pool.

- Patent commons: Generally broader in scope than patent pools, patent commons allow technology holders to pledge their patented technologies for widespread use for no royalty payment - usually subject to certain general conditions (for instance, agreement not to enforce rights over technologies resulting from access to the commons). Participants may, for instance, legally pledge or covenant not to assert their patent rights against those implementing the technology in certain humanitarian or other public interest domains.

- License of right: In the patent law of some countries, a 'license of right' system provides for a reduction in official fees for patent holders who agree to make their patented technology available to anyone requesting a license, subject to terms that can be negotiated or determined by the authorities. The UK Patent Office, for instance, maintains a database of patented technology that is endorsed as available for a license of right.

- Non-assertion pledge or covenant: Rather than canceling or abandoning their patents, patent holders may choose to make their technology widely available by legally pledging not to assert their patent rights against anyone using the technology. This may be restricted to specific uses of the technology (such as for specific public health research and development activities), limited to certain geographical locations (such as countries below a certain average level of income), or conditional on the person who uses the technology making available improvements or derivative inventions on similar terms (in the spirit of a 'commons').

- Humanitarian or preferential licensing: This type of licensing technology policy provides highly favorable or free terms to certain beneficiaries, for example, developing country recipients, social marketing programs, or public sector/philanthropic initiatives.

- Public domain: Placing technologies directly in the public domain is one avenue for their transfer and dissemination. Often, technologies are patented in a relatively small number of countries, effectively placing them in the public domain in all other countries as soon as the patent applications are published. New technologies may be consigned to the public domain, so that anyone is free to use them without legal constraint (unless, of course, health and safety, environmental, ethical or other regulations apply), by the simple act of publishing or otherwise communicating them to the public. Special patent search tools can identify those technologies that have entered the public domain when patents lapse or expire.

- Open innovation, open source, commons-based peer production and distributed innovation: This cluster of related concepts features in current discussions about innovation models that emphasize a collaborative or shared technological platform for innovation. The term 'open source' originated from a software development model that ensures access to the humanreadable 'source code,' and permits others to use and adapt the software, and to redistribute it, whether or not it is modified. Open source is also now used as a metaphor or description for other fields of innovation in which a technological platform is left open to others to use and adapt, and, on the basis of which, innovations can in turn be shared, for instance, open source biotechnology [15].

'Open innovation' describes a similar but broader approach, emphasizing the interest of many firms in seeking synergies and collaboration with other actors working on related technologies, as opposed to closed innovation which would emphasize firm boundaries between rival companies: according to one definition, open innovation is "combining internal and external 
ideas as well as internal and external paths to market to advance the development of new technologies."

- 'Commons-based peer production' refers to the development of new products through widespread collaborative networks without a formal hierarchy, often brought about by a sense of collective purpose: the Wikipedia online encyclopedia is a good example. 'Distributed innovation' refers to the development of innovative products through collective efforts in networks spanning different organizations, institutions or individuals.

In practice, these different models entail establishing a strategic framework and clear overall objectives to help guide and inform tactical choices over specific practical options:

- Publication: what is published, and when, both in order to advance the diffusion of knowledge, and to safeguard freedom to operate by establishing unambiguous public domain status.

- Partnerships: what relationships are envisaged with what external partners; to the extent that private sector resources are determined to be useful, what positive inducements can be offered to secure those resources, whether these are product development capital, capacity to manage liability and risk, product development know-how and infrastructure, needed background or manufacturing and delivery technologies, or regulatory dossiers; what guarantees are required to ensure that these resources and capacities will be available and effectively delivered; and what fallback options, march-in rights and other guarantees of access will apply in the event that one partner is unwilling or unable to meet expectations.

- $\quad$ Obtaining IP (typically patents): for what specific inventions are patents to be sought; for what practical purpose; in what jurisdictions; in whose name; and with whose funds.

- Exercising IP: should patents be successfully obtained, who is to administer the patent estate; and again for what purpose, potentially distinguished according to jurisdiction (for instance whether developed or developing countries), market (public sector, philanthropic, or private), field of medical application (diseases of affluence or lifestyle diseases, as against neglected diseases or diseases endemic in the developing world); who is to fund and to enforce patents, again, potentially broken down by jurisdiction;

- Licensing and sharing IP: in line with overall objectives, what licensing models are to be pursued, and to what end: maximising leverage in order to secure additional resources or background technologies; maintaining leverage over the application of key technologies so as to ensure continuing openness of access; bolstering local research and development, including building up necessary capital investment, infrastructure and product development know-how; focusing on specific interventions in the form of precise research and development outcomes, such as a new vaccine or treatment for a neglected disease.

\section{PUBLIC INTEREST AND THE RIGHT TO EXCLUDE: MANAGING GENE PATENTS}

The complex operational interplay between public and private is illustrated in the highly topical instance of the patenting of BRCA1 and BRCA2 genes. These tumour-suppressor genes code for proteins that repair damaged DNA, and regulate the growth of cancerous cells. Mutations in these genes increase the risk of breast and ovarian cancer, so the genes are useful diagnostics for susceptibility to these diseases. Few recent patents have been as controversial as the "Myriad Genetics" patents on these genes [16]. These patents provoked intense criticism and legal opposition in Europe and assertion of public use rights in Canada [17], due to concern about their impact on the public interest. Critics focused especially on the restrictive licensing policy employed by Myriad, which reportedly entailed actively restricting academic research using the patented gene [18], and was labeled 'abusive,' "immoral" and "unethical" in some critical accounts. ${ }^{23} \mathrm{~A}$ broad coalition of public health, research and civil society actors opposed European patents. ${ }^{24}$ The rationale for the opposition against the patent went well beyond the strict patentability of the claimed subject matter, and addressed the underlying concern related to the negative social impact that the patent was felt to have: in particular, it constrained the use of a genetic diagnostic for susceptibility to ovarian or breast cancer. The European Patent Office (EPO), when issuing a press release concerning this opposition, felt constrained to point out that it "has not been vested with the task of taking into account the economic effects of the grant of patents in specific areas [19]." This statement, and the wide-ranging controversy it responds to, together underscore the difficult task of distinguishing between pre-grant regulation of the public interest through the accurate application of patentability criteria, and post-grant regulation of the exercise and public-interest impact of otherwise technicallyvalid patents.

In effect, the opposition to the patents operated at three levels: blanket opposition to the very idea of gene patenting, as a fundamental policy concern; challenging the validity of these patents under existing patent law; and concern about how the patented technologies were licensed, which was felt

\footnotetext{
${ }^{23}$ e.g. in Keeping Science Open: the Effects of Intellectual Property Policy on the Conduct of Science, Royal Society, 2003, at 10, citing also Wadman, Testing time for gene patent as Europe rebels, Nature 413 (2002), pp. 443.

${ }^{24}$ EP 705902 was opposed by the Social Democratic Party of Switzerland, Berne; Greenpeace Germany, Hamburg; the Institut Curie, Paris; Assistance publique - Hôpitaux de Paris, Paris; the Institut Gustave Roussy, Villejuif (F); the Belgian Society of Human Genetics et al., Brussels; Dr Wilhelms, Göhrde (D); the Netherlands, represented by the Ministry of Health, The Hague; and the Austrian Federal Ministry of Social Security, Vienna; and EP 705903 was opposed by the Institut Curie; Assistance publique Hôpitaux de Paris; the Institut Gustave Roussy; the Vereniging van Stichtingen Klinische Genetica, Leiden (NL); the Netherlands, represented by the Ministry of Health; and Greenpeace Germany.
} 


\section{The BRCA Discovery Model}

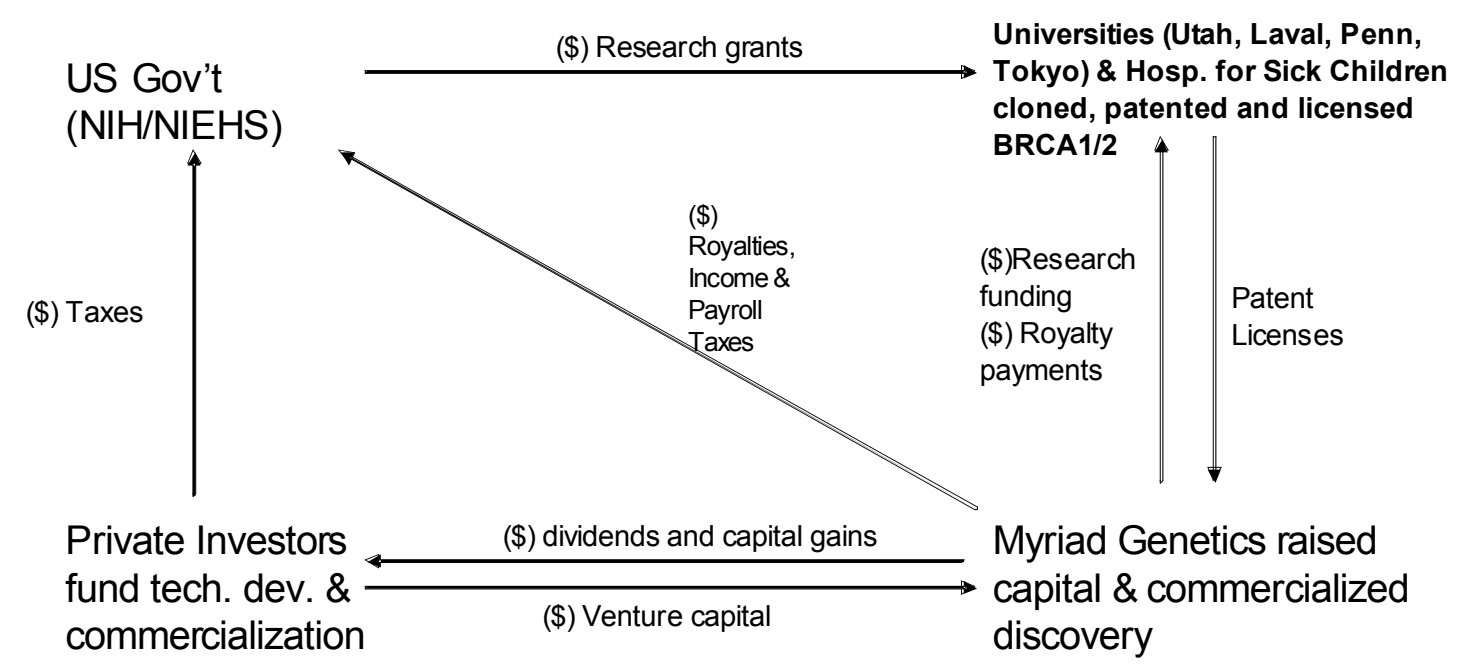

Fig. (2). Outline of the innovation financing structure reportedly applied in the development of diagnostic tests by Myriad Genetics, extracted from Rusconi, W. "Health diagnostics: to whom, what and why" [23].

to impose unreasonable costs on public health providers and to limit necessary cancer research. Uniting these three layers was a background concern about the impact on effective and equitable universal access to this important diagnostic tool. In considering the impact of the IP system on public health, and its potentially positive role in fulfilling a right to health, it is therefore necessary to clarify the distinct impacts on these three levels.

The Myriad case, in particular, alerts us to the need to consider patterns of ownership and licensing of the patents in question, apart from their technical validity. Key "Myriad" patents held by a public institution, University of Utah (a state university), and a national government, the United States (represented by the official responsible for public health policy, the Secretary, Department of Health and Human Services). Several patents were not held by a private company at all, although Myriad held exclusive licenses. Further, when this patenting activity came to light, a patent application on the BRCA2 gene was filed by Cancer Research Technology Ltd, the technology licensing arm of a British cancer research charity, and this matured into a granted patent in 2004. The patentee immediately announced that it would freely license the use of this patent to public laboratories. The grant of this patent and this open licensing structure were positively welcomed by a number of the critics of the original Myriad patents. Gert Matthijs, head of molecular diagnostics at the University Hospital Leuven, who was active in the opposition proceedings, expressed "strong appreciation to Cancer Research UK because they have chosen to offer royalty-free licenses on its patent on the BRCA2 gene to public health services in European countries [20]."

While the BRCA cases raise many legal and policy issues, they illustrate firstly that many privately-exercised health-related technologies are not in private hands, strictly speaking, but are held by various public and public-interest entities, and secondly that modes of licensing may be far more significant in ensuring equitable access than "pure" questions of patentability, or technical validity. Matthijs suggests, on the basis of the BRCA cases, that a "system rather like royalties for use of music might be one way forward to reimburse researchers for the costs of discovering genes and then make them available to others at an affordable price," in other words, a distinct liability regime for gene patents in particular, under which the patentee would simply be entitled to an equitable remuneration and could not obtain injunctive relief. ${ }^{25}$ The Nuffield Council on Bioethics concluded "that the protection by use patents of specific diagnostic tests which are based on DNA sequences could provide an effective means of rewarding the inventor while providing an incentive for others to develop alternative tests" but that for "patents that have been granted for diagnostic tests based on genes, compulsory licensing may be required to ensure reasonable licensing terms are available to enable alternative tests to be developed [21]."

More recently, in the United States, two patents on BRCA genes held by Myriad Genetics have been challenged by the American Civil Liberties Union among others on the basis that the patents are unconstitutional and invalid [22]. The complaint filed addressed the inherent patentability of nucleotide sequences isolated from the human genome, but also cited concerns about specific consequences 'because Myriad chooses not to license the patents broadly.' This paper advances no position on the merits or the basis of these

\footnotetext{
${ }^{25}$ This already can apply within the standards of the Trips Agreement for public non-commercial use of patented inventions: TRIPS Article 44.2 means that patent law may limit the remedies available to compensation only, and may preclude the possibility of an injunction.
} 
claims; the case is cited only to demonstrate that there is in such cases a clear connection between claims about the welfare impact of patents as such, and the choices made in the deployment of those patents - the IP management choices.

For its part, representatives of Myriad [23] have pointed out that this innovation model (see Fig. 2) [11] enables: (i) investment to develop the discovery for the public benefit; (ii) funding and resources for further research (royalties, licensing fees, taxes, etc.; (iii) investment in improvements to further enhance the quality of the test and genetic services; (iv) investment in provider education to expand service and access ; and (v) better healthcare.

Thus, the "Myriad" case - from a critical perspective, viewed as an example of private-sector interests trumping sound public health policy - can also be seen as epitomizing the contrast between two conflicting perspectives on the management of public-sector assets and of the optimal financing of public goods in the public health domain. The "privatized" approach actually makes use of a patent held by a national government and a state university, which is licensed to a private company, formed as a spin-off from the University as a market-based means of promoting technology transfer to the public; the open, public-licensing approach is undertaken by a private company (wholly-owned by an independent charity) which owns and licences the relevant patent in conjunction with a private university. Myriad was reportedly in 2006 yet to turn a profit, largely because of its high expenditures on research and development, its accumulated losses by the end of 2005 amounting to some $\$ 180 \mathrm{mn}$ [24], recalling that its very existence stems in part from a perceived past failure to garner the resources for outcome-oriented product development through exclusively public means.

Indeed, the exercise of the Myriad patents is not an example of pure private interest, but rather the consequence of a conscious public policy choice made by the United States [24], expressed in the form of the Bayh-Dole Act. ${ }^{26}$ Behind this 1980 legislation is perhaps a perception that governments are ill-suited and under-funded to undertake the management of IP that is required to bring an invention to the public in the form of a practical product, even where the underlying research is financed by the public purse. This reportedly led to a kind of market failure in the delivery of new technologies to the public, including in such crucial areas as medical technology: by one account, by 1980 , "the Government had accumulated in its patent portfolio about 30,000 patents of which only about $5 \%$ had been licensed to industry with an even smaller percentage reflected in products or processes in commercial use [25]."

Bayh-Dole required public universities to establish technology licensing offices, to implement this form of public knowledge management. The Utah Technology Commercialization Office describes its goals as including generating revenue for the University, promoting economic growth in the State of Utah, and ensuring public benefit from

\footnotetext{
${ }^{26} 35$ U.S.C. $\S 200-212$.
}

technologies developed by the University [26]. Bayh-Dole is possibly the most widely-analysed and debated model for management of publicly-funded knowledge, but this statutory approach is only one avenue among a number of possibilities, at several levels of institutional and regulatory frameworks. The full range of potential mechanisms to manage IP directly to promote public interest goals in the field of public health include:

- $\quad$ statutory law [27], which may be reflected directly in national patent laws, ${ }^{27}$ and specific laws governing university research ${ }^{28}$

- $\quad$ national policies governing the use of public funds for research;

- $\quad$ the policies of specific funding agencies;

- the policy and practice of public research institutes, and technology management associations [28];

- $\quad$ the policy and practice of specific entities established to promote public-interest health research and development (in particular, the highly-focused "public-private partnerships (PPPs)" created to focus resources on creating new products to address neglected health needs) [29];

- distinct incentive mechanisms such as prize funds, including models that would altogether dispense with or limit the application of IP rights.

While these forms of intervention differ considerably in their legal status and practical operation, they all represent attempts to address the question of how to deploy statutory exclusive rights so as to promote the public interest. Some are specific to the public health sector; others concentrate on that sector in practice because of the high level of public funding devoted to public health research, in contrast to most other areas of technology. Behind the policy choices in these mechanisms is the need to take account of the actual innovation structures that are emerging in the medical domain. The discovery and development of new drugs and vaccines typically require diverse resources and inputs both from public sources and from private industry. The extent and nature of these inputs naturally differ widely in distinct innovation processes, and the comparative value of private as against public inputs in health innovation is debated in general. Allocation of resources is now a critical issue for diseases and health needs which have been neglected by market-driven development processes.

Policymakers who seek optimal structures and interventions to overcome neglect and deficiencies in available public health technologies are therefore probing the

\footnotetext{
${ }^{27}$ e.g. United States Code Title 35 - Patents, Chapter 18 - Patent Rights In Inventions Made With Federal Assistance, 35 U.S.C. 200 Policy and objective: "It is the policy and objective of the Congress to use the patent system to promote the utilization of inventions arising from federally supported research or development;... to ensure that the Government obtains sufficient rights in federally supported inventions to meet the needs of the Government and protect the public against nonuse or unreasonable use of inventions...."

${ }^{28}$ E.g. Austria, 2002 Law concerning Universities.
} 
interface between public and private inputs in medical research and development. For governmental, international and philanthropic funding agencies and other public health initiatives, finding the right interface between public and private inputs is an immediate practical need. This interface is inherently complex, but is defined in part by a range of IP laws, standards and management strategies. The IP system is conventionally viewed as a legally-determined 'balance' between public and private interests, framed in legislation and shaped by international standards. Debate revolves around whether, and how, IP law should be interpreted through, or subordinated to, public policy objectives and other international law principles, notably the right to health. Yet this balance is dynamic, and its overall beneficial impact is achieved through the concretion over time of many distinct acts in the practical exercise of rights, interests and legal safeguards.

The formal legal framework defines a policy and legal space, but gives limited practical guidance on optimal choices and public health strategies within that space. Accordingly, public-interest IP management is emerging as a priority in bridging the 10/90-health research gap - the finding of the Commission on Health Research for Development that less than $10 \%$ of global health research resources are applied to the health burdens is of developing countries, which amount to more than $90 \%$ of the world's health problems [30]. Different approaches to ownership and access of IP, guarantee of public interest, and market and non-market incentives, including transjurisdictional tradeoffs, can leverage otherwise unobtainable public health benefits; but simply to invoke 'IP' as an innovation model or to foreswear it as an innovation model does not in itself provide practical guidance to public sector knowledge managers seeking to advance public health objectives.

From this analysis, ex-ante IP management strategies need to assess public sector needs before and during the interface with the private sector. This entails making systematic choices about managing IP interests during the initial funding and $R \& D$ phases, so that public sector players can structure and define their interaction with the private sector to promote public health benefits. This approach contrasts with discussions centering on ex-post interventions, when IP typically serves as a symbol for asymmetries of ownership and access, and the public interest is characterized by negotiations over pricing, or the threat or implementation of compulsory licensing and government use mechanisms; these are essentially public-interest remedies, rather than strategic management of collective knowledge goods. A comprehensive, strategic approach would address the undermanagement of public IP interests integrally during the research and development process. Combined with limited awareness of practical enabling strategies within the IP policy and legal space, an exclusive focus on ex-post intervention can constrict public health outcomes. Ideally, ex-ante IP management would positively to construct pathways for equitable outcomes and enhanced access for the poor to finished medical products, while promoting dynamic innovation, empowering low and middle income countries to secure indigenous public health solutions, and to meet the Millennium Development Goals relating to public health and partnership for development [31].

This entails studying the practical options for managing IP to promote the creation, development and effective dissemination of medical research outcomes for neglected diseases or diseases of poverty [32]. In contrast to the diseases prevalent in industrialized countries, established drug development processes have given scant attention to a number of widespread infectious diseases that are suffered by the poor and predominantly afflict the developing world. The research and development effort falls well short of the level of need proportionate with the scale of this disease burden. This 'fatal imbalance' [33] has led to calls for international policy initiatives to refocus research and drug development. ${ }^{29}$ The challenges for the creation and delivery of new treatments for neglected diseases include:

- identifying promising leads and creating new candidate compounds, an essentially scientific activity applying basic research capacity to neglected diseases;

- transforming compounds into new medicines, entailing extensive clinical testing, regulatory approval, and access to associated technologies, manufacturing capacity and delivery platforms;

- health infrastructure, distribution chain and cost issues which can determine how many patients gain access to new medicines and how effectively they are delivered and administered within the context of overall health care.

Analysis of the problem of neglected diseases has highlighted impediments or shortcomings at each of these stages, but emphasis has been laid on the need to improve the drug development pipeline, since there is evidence of promising new compounds remaining undeveloped due to the lack of incentives to take such compounds through the development process. ${ }^{30}$ Policy settings are also seen as an obstacle to translating medical knowledge into actual tangible benefits, where the basic science is well known and current technology offers solutions in principle. ${ }^{31}$ There are diverse possible structures for filling this drug development gap, which draw on a range of inputs and are adapted to the practical needs in each case.

Both public and private inputs have in practice been vital in achieving public health outcomes: one estimate indicates that of the more than US\$70 bn invested in global health R\&D in $1998,50 \%$ of the funds came from public sources, and $50 \%$ from private sources $(84 \%$ of which was provided by the pharmaceutical industry, the remainder from private not-for profit funding) [34]. The private sector role has been

\footnotetext{
${ }^{29}$ For example, Carlos Morel, 'Neglected diseases: under-funded research and inadequate health interventions,' EMBO Reports, Vol. 4, 2003, at p. S35.

${ }^{30}$ Numerous promising drug and vaccine leads are sitting on the shelf. It is time for pharmaceutical science to deliver on its tremendous promise for the developing world,' Dr. Victoria Hale, at www.oneworldhealth.org.

${ }^{31}$ This point is made by Alimuddin Zumla, 'Reflection \& Reaction: Drugs for Neglected Diseases,' The Lancet Infectious Diseases, Vol. 2 (July 2002), p. 393.
} 
important when research moves beyond basic science to the clinical trials and other development steps required to prove the efficacy and safety of new products and to bring them to fruition as readily available treatments. The scientific and technical skills that are the traditional strengths of the research community need to be supplemented by crossdisciplinary expertise in product development, regulatory processes, production and distribution. ${ }^{32}$ Both sets of skills are vital for the pharmaceutical development process, whether it is public-funded or based in the private-sector.

Hence even publicly-funded research programs have entailed some form of engagement of private sector entities at some stage as the initial research breakthrough is taken from the laboratory to the dispensary, to be available to the public as a proven, tested, stable, mass produced and efficacious pharmaceutical. In this process, public and private inputs may be required, both to marshal the necessary resources and development skills, and to secure access to associated technologies and know how. So the immediate and pressing concerns about major public health problems tap into the broader, long-running public policy debate: how best to promote innovative research and development in the private sector, and to focus it on areas of need, while still ensuring effective public availability of new technologies for the overall welfare of society? How to encourage private activity that promotes the broader public interest? It is perhaps inevitable, then, that the debate turns to some extent on the role and effect of patents in the health domain. Patents are intended to promote innovative private sector activity (research and investment in development of new technologies) for the overall public good, but how to optimize the public interest, especially public health outcomes, within the patent framework remains a contested issue.

\section{PRACTICAL LESSONS FROM PUBLIC PRIVATE PARTNERSHIPS}

One specific vantage point from which to review these issues is to consider a tailor-made mechanism for harnessing private interests to achieve specific public health outcomes the public private partnership (PPP) agreements created to address neglected needs for medical research and development. These partnerships typically aim to achieve two distinct outcomes - first, creating a new technology (such as a new pharmaceutical treatment or vaccine), ${ }^{33}$ and

\footnotetext{
${ }^{32}$ 'While supporting basic and drug-lead discovery research, the public sector has rarely developed its own drug development expertise and capacity. It is the pharmaceutical industry that leads product development, from pre-clinical research through regulatory approval,' 'Fatal Imbalance, The Crisis in Research and Development for Drugs for Neglected Diseases,' MSF and DND Working Group, 2001, p.20.

${ }^{33}$ These may be formally structured partnerships or other distinct initiatives with a specific objectives to develop and disseminate new medical products; widely discussed examples include Medicines for Malaria Venture (MMV) (http://www.mmv.org), International Partnership for Microbicides (http://www.ipm-microbicides.org). Drugs for Neglected Diseases Initiative (DNDi), Medicines for Malaria Venture (MMV), the Malaria Vaccine Initiative (MVI), the International AIDS Vaccine Initiative (IAVI), the Institute for One World Health (IOWH) and the Global Alliance for TB Drug Development (GATB). Partnerships may also be more ad hoc in character, such as cooperation between industry and the U.S. Walter Reed Army Institute of Research to develop antimalarial medicines.
}

second, ensuring that this technology is practically available as a safe and effective finished product to as many intended beneficiaries as possible - this means some mix of positive incentives and contractual guarantees that ensure the finished product will be distributed well beyond the scope that the regular commercial market would service. A report prepared for the World Health Organization Commission on Intellectual Property Rights, Innovation and Public Health distinguished PPPs for product development for neglected diseases from PPPs focussed on access to existing drugs:

product development public/private partnerships
(PDPPPs) focused on the development of new
drugs, vaccines, and other products for diseases
that disproportionately affect developing
countries. PDPPPs are nonprofit entities that
sponsor others to perform or directly perform
themselves at least one of the following R\&D
activities: basic research (such as target
identification, validation and proof of concept),
animal, preclinical and clinical testing,
licensing, and manufacturing. The successful
PDPPP may also be responsible for distribution.
PDPPPs are distinguished from Access PPPs,
which are nonprofit entities concerned primarily
with expanding access by pulling together
manufacturers, funding agencies (such as
GAVI, USAID) and developing countries to
enable the purchase and distribution of existing
drugs, vaccines, and other medical products
[35].

The focus of this paper is not a detailed analysis of PPPs, and rather a review of options at a broader level, no views are offered here on exact classification issues, and examples are cited for illustrative purposes only. More detailed studies are available on some of the specific choices that are discussed here in much more general terms [36]. PPP mechanisms, as agreements governing a relationship between public/philanthropic entities and private sector partners, naturally entail careful definition of rights and expectations concerning background IP (IP that both or either partners may bring to the partnership) and research or project IP (IP generated in the course of funded research and development, which may be fundamental in nature, or may be improvements, developments of existing technologies, or new applications). Hence PPPs usually require both a strategic, policy-oriented approach to IP issues (since they are typically conceived as addressing unmet needs that the existing systems have failed to serve), and a pragmatic, tactical use of IP and agreements on IP management to generate the desired outcomes (given that they also aim to ensure as a practical result the widest effective access to an actual finished product among neglected communities). PPPs have been established consciously to build alternative pathways to the creation and equitable dissemination of new medical treatments. Yet the economics and infrastructure of medical R\&D mean that private players will have to be involved: " $[t]$ he public research community ... is primarily involved in the early phases of basic research and drug discovery. The expertise, infrastructure and management capacity for moving these discoveries through the drug 
development process is concentrated in the private sector [37]." Accordingly, the approach to IP management - the choices made by PPPs to seek and assert the exclusive rights granted under the IP system - will provide insights into the broader policy issue of how to define and promote a clearer, more effective contribution on the part of private sector interests towards the goal of stronger public health outcomes in geographical areas and for diseases that have been poorly serviced by the conventional drug development processes. In short, they illustrate in microcosm the overarching question of how to manage IP-based exclusivity to harness private resources so as to yield inclusive public health outcomes, enable direct and focused way that simply relying on the 'invisible hand.'

When such partnerships involve the research and development of new technologies, IP is managed through a range of diverse strategies to achieve certain defined public health goals by: ${ }^{34}$

- $\quad$ arranging ownership and maintenance of IP generated by the new research they commission, including arrangements that respect different conditions (e.g. the private sector player maintaining rights to markets in rich countries, as a condition of ceding rights for developing country markets);

- leveraging IP to ensure access to background, related IP that is needed either for the research or the development and implementation phase;

-

provisions on licensing new technologies (such as favorable conditions for the private sector player for target markets - public sector or developing country markets - possibly in exchange for access to rich markets);

- undertakings on specific steps to make new product available, backed by guarantees on access to necessary IP for third parties - e.g. to test data, background technology, manufacturing know-how in the event that the private sector partner fails to meet the agreed public interest criteria for dissemination of the new product.

What is striking about the approach taken in managing IP by these PPP initiatives is the fundamental pragmatism that is applied. IP is seen simply as an implement or practical mechanism to achieve the public-interests of the initiative. For example, the Drugs for Neglected Diseases Initiative (DNDi) [38] was consciously created as a non-market alternative to drug development, amidst a climate of concern and criticism directed at conventional pathways, and their limitations, due in part to the impact of the patent system [39]. It has adopted an IP policy that foresees a distinct, if limited, role for IP management to achieve its objectives; for instance, the policy recognizes that it is possible that promoting DNDi's mission and goals will sometimes require

\footnotetext{
${ }^{34}$ See Antony Taubman, Public-private management of intellectual property for public health outcomes in the developing world: the lessons of access conditions in research and development agreements, Initiative on PublicPrivate Partnerships for Health (IPPPH), Geneva 2004, at http://www.globalforumhealth.org/filesupld/ippphV̈cd/04.PDF.
}

outputs to be protected by IP" even if, " [g]iven the costs involved, patenting is likely to be the exception rather than the rule" and "non-patent types of IP such as confidential information ... and copyrights will also need to be considered [40]." In particular, it may be necessary " to deal with IP to conclude contracts and undertake research with its research partners, contractors, collaborators and founders; obtain rights to work on and develop molecules, including facilitating DNDi's or its partners' access to proprietary research materials; and ensure equitable access to, and affordability of, the end products of its research for patients [40]." It then elaborates how IP management will be undertaken to retain full freedom to operate, including using assignment of IP to DNDi, exclusive licences and licences of right. DNDi would "negotiate terms with partners to ensure that they will not use the acquired and/or held IP in a manner that impedes equitable and affordable access to the products of the research, or that impedes additional or follow-on research by DNDi, its partners and other researchers, especially those undertaking research on neglected diseases [40]." It would ensure "the availability and affordability of neglected disease therapeutics" by transferring or outlicensing technologies "to facilitate manufacturing and distribution of its products [11]." This pragmatic approach does not mean that the management of IP occurs in a policy vacuum: "in addition to a pragmatic day to day approach on IP the DNDi is committed to contribute to the thinking and development of IP approaches in health R\&D that are aimed at serving the public good [40]." Indeed, the lessons from practical experience in product development and dissemination are vital inputs to the policymaking process, as a valuable reality check for a policy debate that can veer into abstractions. And, by definition, this pragmatic approach can of course preclude use of the patent system altogether: the first product released by the DNDi initiative [41], ASAQ, a new fixed-dose combination of artesunate (AS) and amodiaquine (AQ), was released for dispensation throughout sub-Saharan Africa having been developed under DNDi management in partnership with sanofi-aventis. The drug is reportedly to be available at a "no profit-no loss" price to "public organizations of endemic countries, international institutions, NGOs, and programs promoting access to drugs in pharmacies [41]." DNDi pointed out that the "fact that ASAQ is made so affordable right from the start and is not under patent removes a significant barrier to its availability and should serve as a model for future drug development for neglected diseases." ${ }^{, 35}$ Another IP tool, trademarks, are used to distinguish the distribution of the treatment to public markets, and its distribution at a higher price to private markets (under the mark Coarsucam ${ }^{\mathbb{B}}$ ), a tiered pricing scheme with the effect of cross subsidizing low cost public distribution from the private market.

The International AIDS Vaccine Initiative (IAVI), a notfor-profit entity, points out that as "much of the expertise in the field [of HIV vaccine science] resides in the private sector, it is vital to promote investment from private industry" yet that IP "should be managed with multiple goals

\footnotetext{
${ }^{35}$ Dr. Bernard Pecoul, DNDi Executive Director, [41].
} 
in mind: the need to promote innovation and investment, as well as the need to ensure future vaccines are made available to poorer countries at affordable prices [42]." IAVI has sought patents on several inventions, ${ }^{36}$ noting that "IP rights can and should be managed to support widespread access to health technologies, particularly in the developing world [42]" citing such means as:

- $\quad$ "segmenting markets to allow tiered (or differential) pricing for different countries, depending on their ability to pay, or by retaining licenses for use."

- $\quad$ stipulating that any licensee of its patent technology "uses it in a manner consistent with our mission of providing poorer countries affordable access to health technologies".

- $\quad$ "Ensuring that the technology will be made available in those countries even if the partner fails to meet its commitment" through "march-in rights," that "typically provide IAVI with guarantees that the technology, data, materials and licenses needed to manufacture and deliver the vaccine will be transferred to IAVI."

- "access commitments" providing that any vaccine "will be promptly registered, manufactured in adequate quantities and distributed at reasonable prices in the developing world" subject to differential pricing: a vaccine is available in developed countries at market prices, but "must be made available in the developing world at an affordable price".

While working in different therapeutic fields from DNDi, IAVI similarly stresses the pragmatic focus of its approach: "having a wide range of partner organizations requires IAVI to approach IP management with flexibility, but based on [the] two clear needs" of accelerating "the development of safe, effective, preventive AIDS vaccines" and ensuring "they will be made available in developing countries rapidly after licensure, at reasonable prices, and in sufficient quantities." It points to the need to explore new ways of using IP to structure and define partnerships, and in particular to leverage access, so that "IAVI's research partnerships include novel intellectual property provisions to maximize future access in developing countries to the fruits of IAVI's R\&D [43]."

Actual experiences of PPPs shed light on several aspects of how the diverse inputs into new products are garnered and deployed, in particular:

- $\quad$ How formal legal structures define partnerships and capture the mutual expectations of widely diverse actors are defined, bridging between commercial and public interest actors and value systems, and between

\footnotetext{
${ }^{36}$ See e.g. international patent applications WO 2007/143606 (HIV-1 Clade A Consensus Sequences, Antigens, And Transgenes); WO 2007/127372, Genetic Adjuvants For Viral Vaccines; WO 2005/047483, Renta: An HIV Immunogen And Uses Thereof; WO 2001/047955, Improvements In Or Relating To Immune Responses To HIV; WO 2001/031046, Invasive Bacterial Vectors For Expressing Alphavirus Replicons (several have since matured into national patents, now in force).
}

differing perspectives of funding and industry partners, so as to reinforce shared objectives.

- The pragmatic construction of differing roles and the different allocation of resources, rights and responsibilities necessary to achieve defined public health goals.

- A broader understanding of practical means of resolving the public policy dilemma of balancing private incentive to generate needed public health products against the goal of guaranteed access to those in need.

The focus on delivery of concrete outcomes requires careful consideration of the target groups, disease burdens, and drug dissemination strategy that then shape specific IP management choices geared to delivering the required new public health interventions. For instance, IP management may be structured to free up other (richer) markets or other (more profitable) indications for a private sector partner, thus enabling effective cross-subsidization of the development and dissemination of products for poorly resourced or otherwise neglected patients. Effective IP management may further save costs and resources, by enabling burden sharing for clinical trials and the use of test data for regulatory approval.

Public interest IP management may entail planning for access to new medicines at two levels - as a pressing policy issue and as an immediate practical need. Policy and practical perspectives can inform the development and greater understanding of hybrid forms of IP management that would give funding agencies, government authorities and philanthropic initiatives bargaining power, leverage over technologies they help develop, freedom to operate in serving their target areas for delivery of new medicines, and the capacity to catalyze new resources and negotiate access to the panoply of technologies needed to deliver affordably a new drug that is safe and effective. Equally, there is a practical imperative to offer rivate sector players enough legal clarity and workable commercial structures that enable commitment of product research, development and manufacturing resources.

Access to new treatments may entail two steps: the creation of R\&D outcomes that would otherwise not exist (due to lack of market interest); and promotion of the widest possible actual availability of a product once it is clinically proven and viable. A review of choices made in PPPs can show how these joint objectives are addressed in parallel, so that practical IP arrangements in the agreements factor in long-term access guarantees at the early stages of research, guarantees that may be determined by

- $\quad$ Setting a price (or more likely a pricing formula) to be available to specific communities (a 'reasonable', 'social marketing,' or 'public sector' price for specific markets, which may effectively be cross-subsidized by the opportunity to secure higher prices under IP protection in other, wealthier markets) 
- Other guaranteed levels of performance (for instance, requiring finished products to be available for defined markets, or establishing timing deadlines, such as ensuring product availability for specified markets within a given time from first entry to any market)

- $\quad$ Reserve ('march-in') rights to access or utilise IP created under the project, in the event that performance levels are not attained, potentially including not only directly funded research IP, but all the necessary IP to put the technology into effect, which may extend to background IP, manufacturing know how or reference to regulatory dossiers)

An access-oriented model of IP management may focus on pragmatically leveraging optimal downstream distribution of a finished product, rather than giving priority to ownership of IP as such, so that ownership can be traded off against targeted performance guarantees, access to related technology and regulatory dossiers, and other mechanisms to promote diffusion among priority recipients. Hence a practical concentration on downstream access can determine basic choices and tradeoffs with commercial partners over:

- ownership of IP that is generated through funded research;

- leveraging access to background or related IP, and other resources such as regulatory data required to bring the desired product to the target communities;

- $\quad$ provisions on licensing new technologies (such as favorable conditions for target markets);

- undertakings on specific steps to make new product available for neglected therapeutic uses or for certain priority groups;

- $\quad$ guarantees on access for certain third parties - e.g. to test data, background technology, capacity building to enable priority needs to be served.

One strategy in the creative IP licensing in PPPs is to negotiate access to technologies and other resources beyond the scope of the sponsored research, since the practical delivery of the finished product typically requires considerably more than access to a single technology produced by the research. PPPs may also safeguard access by structuring the partnership to include alternative access pathways in case an industry partner is unable or unwilling to meet agreed performance standards (in particular, failing to meet obligations to make the product available to specific markets); this may entail agreement to provide access in agreed circumstances to:

- background technologies required to ensure that a new product or adapted technology can be made available in the most useful and cost effective manner, including technologies such as manufacturing processes, adjuvants, excipients and delivery technologies;

- $\quad$ test data and support for regulatory approval, so as to reduce any costs, delays or duplication of clinical trials in the introduction of new products or in the dissemination of existing products to new recipients in neglected countries; or

- technology transfer and capacity building so that alternative producers can take up the technology when the originator is unable or unwilling to service certain markets.

Public interest IP management mechanisms put into effect by PPPs may take a pragmatic approach to ownership of IP produced under the partnership arrangements, and not view it as an end in itself. Ownership of IP is potentially a significant cost and a burdensome administrative demand for public sector or philanthropic institutions, and may be more productively traded off against other guarantees of access to covered and background technologies, and guarantees of access to finished pharmaceutical products. On the other hand, ownership brings with it negotiating strength, and guarantees of continuing strong leverage over core technologies. This may be especially important when third parties are involved - such as through open source or patent pool licensing structures - and the assertion of IP rights may be needed to ensure continuing leverage over downstream and third party uses of covered technology, rather than reliance on contractual obligations to safeguard continuing access to improvements or applications of covered technology, since these may be hard to sustain or enforce through contract alone. Using the 'exclusive right' available under IP law to leverage and potentially enforce continuing open source or patent pooling arrangements, and to ensure access to applications or adaptations of core technology, is perhaps the exemplary case of using the exclusive right to ensure inclusion. In practice, the management of IP ownership may also lead to:

- withholding the transfer of IP ownership to an industry partner until it is financially established and clearly established as an effective manager of the covered IP;

- $\quad$ retaining ownership in public/philanthropic hands for target markets, while permitting an industry partner to retain ownership elsewhere, so as to facilitate product development and to harvest the spin off benefits that arise from development of the product for distribution in wealthier markets;

- leaving ownership to an industry partner as an element of the overall trade-off that effectively uses IP to leverage the application of private resources to serve public interest outcomes, the trade-off of ownership being engineered through:

- $\quad$ securing non-ownership guarantees on access to new IP and background IP (such as humanitarian or developed-country licenses, or march in rights when access conditions are not met);

- avoiding the costs and liabilities of maintaining an IP portfolio, while negotiating the necessary access and 
freedom to operate that is required to meet the defined public interest goals.

An essentially pragmatic view would also address squarely how to structure the most effective, optimal form of partnering, as a priority over any specific legal formula; in principle, in establishing the legal structure of a partnership form should follow function, even if in practice there is a tendency to rely on existing formulae and precedents. The structure of the partnership should reflect common understanding of shared values and objectives, recognition of and respect for distinct interests and operational constraints, and the establishment of realistic expectations of the two partners. The structuring of respective rights and obligations is likely to be assisted by consciously recognizing the distinct institutional context of private sector and public sector/philanthropic actors, and seeking a dynamic reconciliation on the basis of acceptance that immediate interests, overall goals and cultural values inevitably diverge; and that lack of confidence and mutual understanding can itself impede or prevent the attainment of shared objectives and the most fruitful pooling of resources. Practical experience may also lead to a reassessment of the assumptions and structures that have underpinned a partnership, and may lead to insights about rights, undertakings, flexibilities and clarifications, as well as the overall mix of incentives and inputs, that could make the project more successful than a mechanism conceived in a more abstract environment and articulated in a legalistic manner.

Partnerships ultimately concern the establishment of obligations for technology development and access. These may address:

- the research and creation of new technology per se, or the availability of necessary technology and associated data

$\bullet$

obligations on the research/industry partner to undertake research and development, and to make available background IP, know-how and associated data (including technical know-how or skills and resources required for product development, clinical trials and regulatory approval know-how, as well as the data on safety and efficacy produced by clinical trials).

Provisions may amount to a positive undertaking - such as an agreement to undertake research or to provide technology - or an obligation to license or transfer IP rights in the event the research/industry partner fails to, or has insufficient interest to, develop and disseminate covered technology in a particular market.

Downstream technology dissemination provisions set conditions for how the covered technology is to be distributed or marked by the research/industry partner

- $\quad$ potentially by setting a price or criterion (such as 'reasonable price' or 'public sector price') for determining the price for distribution in a certain market);
- $\quad$ or stipulating more generally that the pharmaceutical will be 'reasonably available' or otherwise comply with more general criteria;

- $\quad$ and may provide distinct requirements for how the pharmaceutical is to be distributed in distinct markets, such as an undertaking to cross-subsidize developing country or public sector distribution on the basis of preferential pricing;

- $\quad$ or by setting out other conditions defining how access to the covered pharmaceutical should be granted on the basis of market or non-market mechanisms.

In practice, agreements between public and private sector partners differ significantly according to:

- different strategic judgments and assessments about the most effective incentive structure, and the negotiating dynamics that yield a particular agreement;

- the nature of the contributions brought by the two parties - whether the public partner is providing background IP, for example, and funding may support a stand-alone research program or supplement an existing program;

- External, more objective factors, including market and infrastructure issues :

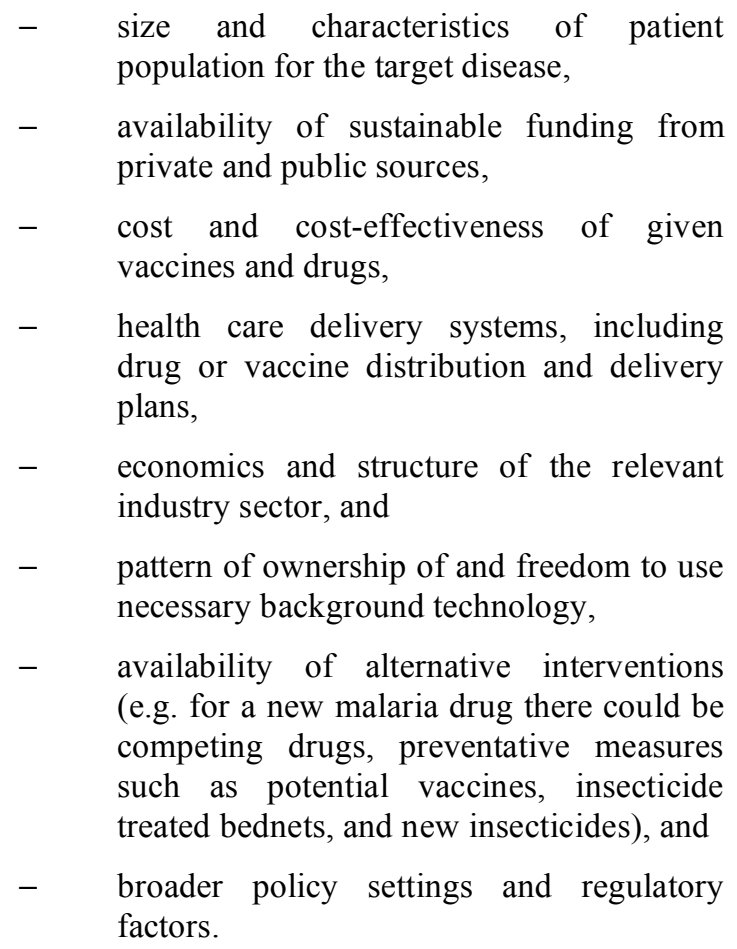

To manage IP in this practical and policy environment directly to achieve public-interest goals will require a hybrid for the IP management skills that applies the same degree of rigour and focus that private firms use to leverage in line with their corporate objectives, but directed towards explicit public-interest goals. Public-private partnerships "must be as aggressive in the way they use IP as any commercial unit, but for a different purpose - namely to pursue their social 
objective of getting quality, affordable products to developing country patients ... [by applying] creative IP arrangements that do not scare off companies but also allow the PPP enough control to ensure their ultimate objective [44]."

Consquently, then, public-interest IP management is based on a pragmatic conception of:

- $\quad$ establishing sufficient public interest guarantees of access;

- $\quad$ building the optimal blend of public funded and private sector research,

- $\quad$ providing incentives to secure investment of private resources, particularly in product development and dissemination capacities when these are not available in the public sector;

- $\quad$ ensuring sufficient safeguards for investment of these resources in the development of a new or adapted product development, so that there is a rational basis to absorb the inherent risk in this process;

- deploying development know-how without unreasonably undercutting the legitimate competitiveness of an industry partner vis-à-vis its competitors;

- $\quad$ and crafting practical partnership structures that are defensible to public sector stakeholders and coherently combine and channel public resources into delivering actual public health outcomes for the defined neglected health needs.

Choices of exact mechanisms to be deployed will be influenced by:

- The lengthy time-frame of product development: ensuring convincing guarantees of access that will be effective over time while being responsive to changed circumstances;

- A realistic approach to price guarantees: a case by case choice between diverse options such as setting a specific formulae for particular markets, setting pricing standards using general criteria, or not requiring specific pricing arrangements, and instead defining access safeguards in other ways or relying on competition to ensure adequate or reasonable access;

- $\quad$ The need for technology access guarantees potentially to cover not just project technology, but an entire technology package (background IP, test data, knowhow, improvements) sufficient to bring a sustainable and viable product to the public;

- $\quad$ The benefits of continuing technical assistance and a comprehensive approach to technology transfer that extends beyond simple freedom to operate in a strict legal sense and ensures practical support for optimal use of the technology.

\section{CONCLUSION}

Public-sector IP management functions as a practical discipline, and illustrates how in practice to reconcile the apparent contradiction between the exercise of exclusive rights and the universal right of access to health. It may be necessary to harness private sector drug development capacity and to apply it in directions that purely commercial interests would not favour. This suggests a broader vision of the operation of the IP system as a form of national knowledge management, directed towards the generation of public goods through channeling private interests, in a more targeted way than a simple laissez faire approach. The exclusive rights conferred by IP enable private sector resources to be deployed to meet neglected public health objectives: the 'lure of gain' condemned by Pindar is to Lincoln the 'fuel of interest.'

Exclusivity, judiciously employed, can translate into positive control over technologies so as to serve the public interest directly - thus it arises, perhaps counterintuitively, that public health advocates could welcome the grant of a BRCA patent to what is technically a private company (a cancer research charity), while opposing a similar patent held by public entities - because the license granted under the privately-held patent provided a guarantee that access to the covered technology would not be rationed by capacity to pay; meanwhile, the management of publicly-held technologies was criticized for excessive use of the leverage available through exclusive rights to provide the fuel of interest, argued to be to the detriment of the broader public welfare. In short, the public interest, and the practical attainment of a right to health, may flow at least as much from the manner in which IP rights are exercised, across a wide spectrum of practical options, as from the formal scope and contours of the IP system conceived as a body of law and the expression of a balancing of interests by the legislature. The emerging discipline of public interest IP management is assuming critical importance as the level and breadth of public ownership of IP rise steadily, just as steadily as the growth in public concern and public expectation that their concrete interests will be served by the just and effective management of these knowledge resources.

It would be facile to suggest that a traditional conception of two distinct public and private spheres in public health innovation is breaking down, if it could ever be coherently identified. It is more accurate to characterize public-private interaction as in a state of rapid evolution towards greater diversity, the scope of interaction broadening to accommodate far greater geographical, cultural, and economic diversity in the use of the patent system. Workable mechanisms for bringing new biomedical innovations to the public may require (1) a range of strategic choices to engage or eschew market mechanisms to various degrees in order to secure the necessary resources and freedom to operate, rather than plumping for a wholly "public" or "private" technology development and dissemination model, and (2) deployment of exclusive rights across a spectrum of greater or lesser degrees of exclusivity and openness, ranging from direct exclusive exploitation or exclusive licensing, through a range of options of decreasing exclusivity, to simple public-domain disclosure. It seems counterintuitive, but some public sector technology-development strategies may require strong degrees of exclusivity, for instance when seeking access to a 
private sector compound library or when negotiating access to an existing regulatory dossier. Equally, private sector players can see commercial advantage in deploying nonexclusive IP management structures, particularly for precompetitive technologies. ${ }^{37}$ Public sector programs may avoid patent coverage for research tools such as cell lines, with a view to facilitating wide application while still using contractual control over access to physical materials to secure financial returns to fund further research. ${ }^{38}$ No single template is likely to be anything but an indicative guide or catalog of options. Ultimately, from a utilitarian perspective, what amounts to good practice in advancing desired public health outcomes is good policy. But what is clear is that the same exclusive right will be viewed very differently if it is held by a private firm, by a public sector agency, or by a private charity, and depending on how it is deployed in practice. The choice to seek or to grant patent protection is not in itself determinative of the public welfare outcomes: much depends on how the exclusive rights are exercised, where, by whom and to what end; and on what institutional policies and on what strategic objectives define and guide IP management choices.

\section{REFERENCES}

[1] Frank J. Pindar's victory odes, Nisetich, translation. USA: Johns Hopkins University Press 1980; p. 171.

[2] Committee on Economic, Social and Cultural Rights, Substantive Issues Arising in the Implementation of the International Covenant on Economic, Social and Cultural Rights, General Comment No. 14 (2000): the right to the highest attainable standard of health (article 12 of the International Covenant on Economic, Social and Cultural Rights), document E/C.12/2000/4, 11 August 2000.

[3] Office of The High Commissioner for Human Rights. Access to medication in the context of pandemics such as HIV/AIDS, tuberculosis and malaria. Commission on Human Rights Resolution, 2004/26.

[4] Pindar, third Pythian ode, supra.

[5] United Nations High Commissioner for Human Rights. Intellectual Property Rights and Human Rights Resolution 2000/7, United Nation Sub-Commission on the Promotion and Protection of Human Rights 2000; at para 7.

[6] Catalogue record. Canada - Patent Protection of Pharmaceutical Products - Complaint by the European Communities and their Member States - Report of the Panel, WT/DS114/R, 2000; at 161.

[7] a) Universal Declaration of Human Rights, article 27, paragraph 2. b) International Covenant on Economic, Social and Cultural Rights (CESCR), article 15, paragraph 1 (c).

[8] Intellectual Property Rights and Human Rights, fn [5] supra resolution 2000/7, United Nation Sub-Commission on the Promotion and Protection of Human Rights, 2000; at para 7.

[9] Intellectual Property Rights and Human Rights, fn [5] supra resolution 2000/7, United Nation Sub-Commission on the Promotion and Protection of Human Rights, 2000; at para 2.

\footnotetext{
${ }^{37}$ The SNP (single-nucleotide polymorphism) consortium and the human genome project are exemplary instances.

${ }^{38}$ For instance, the United States Public Health Service Technology Transfer Manual provides that [the Public Health Service] will generally not seek patent protection for research tools, such as transgenic mice, receptors, or cell lines. Such materials can be licensed effectively in the absence of patent protection, under royalty-bearing biological materials licenses, or distributed to the research community through non royalty-bearing material transfer agreements. For research tools, the public interest is served primarily by ensuring that the tool is widely available to both academic and commercial scientists to advance further scientific discovery. Secondarily, a financial return to the public is obtained through royalties on the rare research tool that has significant commercial value." PHS Licensing Policy, Chapter No. $300,<$ www.nih.gov/news/researchtools/appendd2.htm>
}

[10] Lincoln A. In: Basler R, Ed. Second lecture on discoveries and inventions. Collected Works of Abraham Lincoln 1859.

[11] a) Rawls J. A theory of justice. USA: Harvard University Press 1971. b) Kilcullen R. RAWLS: The Original Position. Macquarie University 1996. Available from: http://www.humanities.mq.edu. au/Ockham/ y64113.html

[12] Marshall A. Industry and Trade, $3^{\text {rd }}$ ed. London: Macmillan \& Co. 1923; p. 457.

[13] Taubman AS. Saving the village: conserving jurisprudential diversity in the international protection of traditional knowledge. In: Maskus KE, Reichman JH, Eds. International Public Goods and Transfer of Technology under a Globalized Intellectual Property Regime. Cambridge: Cambridge University Press 2005.

[14] Taubman A. Several kinds of 'should': the ethics of open source in life sciences innovation. In: Overwalle GV, Ed. Gene Patents and Collaborative Licensing Models Patent Pools, Clearinghouses, Open Source Models and Liability Regimes. Cambridge: Cambridge University Press 2009.

[15] a) European Patent Office (EPO). Breast and ovarian cancer susceptibility gene. EP 705902, 2001. b) European Patent Office (EPO). Mutations in the $17 \mathrm{q}$-linked breast and ovarian cancer susceptibility gene. EP 7059032001.

[16] Eggerston L. Ontario defies US firm's genetic patent, continues cancer screening. CMAJ 2002; 166(4): 494.

[17] Money Isn't Everything, Inside Higher Education. Available at: http://insidehighered.com/news/2006/03/06/technology [Accessed on March 6, 2006].

[18] European Patent Office. Public opposition hearings on two genetic engineering patents "breast cancer gene". European Patent Office: Press Release 2005.

[19] Mayor S. Charity wins BRCA2 patent: genetics researchers welcome a decision that will make the gene freely available in Europe, Available from: http://www.biomedcentral.com/news/ 20040213/02, [Accessed on February 13, 2004]

[20] The Ethics of Patenting DNA (A discussion paper). London: The Nuffield Council on Bioethics 2002, at xi-xii.

[21] Association for Molecular Pathology. United States Patent and Trademark Office, (United States District Court for the Southern District of New York in Manhattan against the PTO, Myriad Genetics and the University of Utah Research Foundation, which hold the patents on the BRCA genes.

[22] Rusconi WE. Health diagnostics: to whom, what and why?" Nordic Committee on Bioethics: Business and bioethics, Malmö, Sweden 2006.

[23] Form 10-Q, Myriad Genetics - MYGN filed at Securities and Exchange Commission, Available at: http://www.sec.gov/edgar. shtml [Acessed on February 7, 2006].

[24] Ganguli P, Prickril B, Khanna R, Eds. Technology Transfer in Biotechnology: A Global Perspective. Bayhing for blood or Doling out cash? Economist 2005.

[25] Bremer HW. The First Two Decades of the Bayh-Dole Act As Public Policy, Presentation to National Association of State Universities and Land Grant Colleges. Availabe at: http://www. nasulgc.org/COTT/Bayh-Dohl/BremerV̈speech.htm [ November $11,2001]$.

[26] http://www.tto.utah.edu/about/aboutVtco.html

[27] Article 30, Japanese Law on Special Measures for Industrial Revitalization (Law No. 131 of 1999); Denmark, 1999 Act on Inventions At Public Research Institutions; Republic of Korea, Technology Transfer Promotion Act; Russian Federation: Legal provision regarding ownership of patents derived from public research funding (March 11, 2003).

[28] Technology Managers for Global Health (TMGH) an educational forum. Special Interest Group of the Association of University Technology Managers 2003.

[29] a)Nishtar S. Public - private 'partnerships' in health - a global call to action, Health Research Policy and Systems 2004, 2: 5; b)Widdus R. Public-private partnerships for health and health care in the developing world. 2004, Available at: www.ippph.org/ index.cfm?page $=/$ ippph/publications\& $\&$ V criteria $=$ publications\&crit \& thechoice $=$ show\&id $=153 \&$ typobj $=1$

[30] Global Forum for Health Research, 10/90 Report on Health Research 2003-2004, 2004, at http://www.globalforumhealth. org/filesupld/1090V̈reportV03 Vं04/109004foreword.pdf

[31] http://www.un.org/millenniumgoals 
[32] Gwatkin DR, Guillot M. The burden of disease among the global poor. Washington: World Bank 2000.

[33] MSF Access to Essential Medicines Campaign and the Drugs for Neglected Diseases Working Group. Fatal imbalance: the crisis in research and development for drugs for neglected diseases Switzerland: Médecins Sans Frontières 2001.

[34] Monitoring Financial Flows for Health Research 2001, Available at: www.globalforumhealth.org

[35] Merz FJ. Intellectual Property and Product Development Public/ Private Partnerships Final Report. World Health Organization, Commission on Intellectual Property Rights, Innovation and Public Health 2005.

[36] Taubman A. Public-Private Management of Intellectual Property for Public Health Outcomes in the Developing World: The Lessons of Access Conditions in Research and Development Agreements, Initiative on Public-Private Partnerships for Health Geneva, 2004; and Cathy Garner, Dealmaking and Intellectual Property Management For Public Interest, teport of a meeting organized by the Initiative on Public-Private Partnershipsfor Health (IPPPH), 2005.
[37] MSF Access to Essential Medicines Campaign, Fatal Imbalance: The Crisis in Research and Development for Drugs for Neglected Diseases Switzerland: Médecins Sans Frontières 2001.

[38] www.dndi.org

[39] Boulet P, Garrison C, t'Hoen E. Drug Patents under the Spotlight, 2003, Available at: http://www.accessmed-msf.org/documents/pate nts $\dot{V} 2003 . p d f$

[40] DNDi's Intellectual Property Policy. Available at: http://dndi. org/cms/public $\mathrm{Vhtml} /$ insidearticleListing.asp?CategoryId=87\&Arti cleId $=320 \&$ TemplateId $=1$

[41] Press Release: New, Once-a-Day Fixed-Dose Combination Against Malaria Now Available at: http://www.dndi.org/pdfVfiles/ press $V$ releaseV̈march 1 1-eng.pdf. [Acessed on March 1st, 2007]

[42] International AIDS Vaccine Initiative (IAVI), Promoting Innovation and Access through Effective Management of Intellectual Property. Available at: www.iavi.org

[43] Learning from the Past, Building for the Future: IAVI Strategic Plan 2008 -2012. Available at: http://www.iavi.org/Lists/IAVIPub lications/attachments/944/IAVIV்StrategicV̇PlanV்2007V்ENG.pdf

[44] Kettler H, Towse A. Public Private Partnerships for Research and Vaccines for Diseases of Poverty, Office of Health Economics 2002.

(C) Antony Taubman; Licensee Bentham Open.

This is an open access article licensed under the terms of the Creative Commons Attribution Non-Commercial License (http://creativecommons.org/licenses/by-nc/ $3.0 /$ ) which permits unrestricted, non-commercial use, distribution and reproduction in any medium, provided the work is properly cited. 